Canadian Journal of Fisheries and Aquatic Sciences Journal canadien des sciences halieutiques et aquatiques

\title{
Rapid changes in age and size at maturity in Lake Erie yellow perch (Perca flavescens) are not explained by harvest
}

\begin{tabular}{|c|c|}
\hline Journal: & Canadian Journal of Fisheries and Aquatic Sciences \\
\hline Manuscript ID & cjfas-2016-0211.R2 \\
\hline Manuscript Type: & Article \\
\hline Date Submitted by the Author: & 03-Apr-2017 \\
\hline Complete List of Authors: & $\begin{array}{l}\text { Gíslason, Davíz; University of Guelph, Integrative Biology } \\
\text { McLaughlin, Robert; University of Guelph, } \\
\text { Robinson, Beren; University of Guelph } \\
\text { Cook, Andy; 2Ontario Ministry of Natural Resources and Forestry, Lake Erie } \\
\text { Management Unit, } 320 \text { Milo Road, R.R. \#2, Wheatley, Ontario, Canada, } \\
\text { NOP 2P0. } \\
\text { Dunlop, Erin; Ontario Ministry of Natural Resources and Forestry, Aquatic } \\
\text { Research and Monitoring Section, } 300 \text { Water Street, PO Box } 7000\end{array}$ \\
\hline $\begin{array}{l}\text { Please Select from this Special } \\
\text { Issues list if applicable: }\end{array}$ & Canadian Fisheries Research Network \\
\hline Keyword: & $\begin{array}{l}\text { Fisheries, Harvest-induced trait change, Laurentian Great Lakes, LIFE } \\
\text { HISTORY < General, Phenotypic plasticity }\end{array}$ \\
\hline
\end{tabular}

\section{SCHOLARONE \\ Manuscripts}


1 Rapid changes in age and size at maturity in Lake Erie yellow perch (Perca flavescens) are

2 not explained by harvest

3 Davíð Gíslason ${ }^{1}$, Robert L. McLaughlin ${ }^{1}$, Beren W. Robinson ${ }^{1}$, Andy Cook $^{2}$, and Erin S.

4 Dunlop ${ }^{3}$.

$5{ }^{1}$ Department of Integrative Biology, University of Guelph, 50 Stone Road E. Guelph, Ontario,

6 Canada, N1G 2W1.

$7 \quad{ }^{2}$ Ontario Ministry of Natural Resources and Forestry, Lake Erie Management Unit, 320 Milo

8 Road, R.R. \#2, Wheatley, Ontario, Canada, N0P 2P0.

$9{ }^{3}$ Aquatic Research and Moinitoring Section, Ontario Ministry of Natural Resources and Forestry, 102140 East Bank Drive, , Peterborough, Ontario, Canada, K9L 0G2.

11

12

13 Key words: Fisheries, Harvest-induced trait change, Laurentian Great Lakes, Life history,

14 Phenotypic plasticity 
15 Abstract: Harvest can change phenotypic traits of populations through immediate demographic 16 consequences, evolutionary responses to harvest selection, or developmental responses by 17 individuals. This study investigated the plastic phenotypic effects of harvest on size and age at 18 maturity in a commercially exploited freshwater fish. We tested an individual growth and life 19 history plasticity model using lagged correlations incorporating how harvesting of ages 2 and 20 older fish influenced the abundance of juvenile fish, resource availability, individual growth 21 rates, and carry-over responses in age and size at maturity. Our test used cohort data for Lake 22 Erie yellow perch (Perca flavescens). Age and size at maturity fluctuated widely and rapidly 23 across 23 cohorts between 1991 and 2013, suggesting phenotypic plasticity contributed strongly 24 to maturation dynamics. The changes in maturity could not be explained by responses to harvest, 25 as expected under the plasticity model. In Lake Erie, age and size at maturity in yellow perch 26 appear to be responding to other drivers, such as harvest-induced dynamics of other fish stocks 27 or ecosystem changes that are independent of harvest. 


\section{Introduction}

The prominent trends in phenotypic traits observed in exploited populations suggest the

30 effects of harvest can extend beyond demographic changes in population size, age structure and sex ratio (Jørgensen et al. 2007; Anderson et al. 2008; Sharpe and Hendry 2009). Nondemographic phenotypic effects of harvest are concerning because any effects on age and length at maturity can result in losses of biodiversity, reduced productivity and economic value (Eikeset et al. 2013), and increased risk of population collapse (Hard et al. 2008; Kuparinen et al. 2011; Pinsky and Palumbi 2014). Harvest can cause phenotypic change through three processes: phenotypic selection within a generation resulting from gear selectivity, evolutionary responses over multiple generations to phenotypic selection acting on heritable phenotypic variation, and plastic growth rate responses and subsequent changes in maturation (Rochet 1998).

Distinguishing among these processes is important because evolutionary changes in phenotypes may be more difficult to reverse than plastic changes when harvest is relaxed (Conover et al. 2009; Dunlop et al. 2009; Enberg et al. 2009). Unfortunately, the relative importance of these processes in harvested natural populations remains uncertain because developmental plastic and evolutionary changes are difficult to infer solely from phenotypic data (Heino et al. 2008; Nusslé et al. 2009). growth rate so that faster growing juveniles mature earlier and at smaller size than slower growing juveniles. This juvenile trade-off links plastic responses in maturation to the influence of resource availability through plastic growth responses. After maturation, individuals allocate 
51 energy to reproduction at the expense of further somatic growth. This generates a trade-off

52 between immature growth and lifetime growth for individuals of similar ages (Stearns 1992).

53 The scope for smaller adult body size in fish is high because size at maturity is approximately

54 two thirds of asymptotic size and earlier maturation at smaller size leads to smaller size at later

55 ages when adult growth rate is reduced following maturation (Charnov and Berrigan 1990).

56 Plasticity in maturation and adult size may be expressed in many fishes when immature growth

57 rate responds to changes in resource availability.

Changes in individual growth rate and maturation may occur in a population when

59 harvest changes per capita resource availability. Harvest that reduces population abundance

60 sufficiently to increase the per capita resource availability can generate density-dependent

61 compensatory responses in individual growth rates (Trippel 1995; Kuparinen and Merilä 2007).

62 These responses are thought to be common in harvested fishes (Lorenzen and Enberg 2002;

63 Engelhard and Heino 2004). Changes in growth of immature individuals are then expected to

64 influence maturation schedules expressed as a change in duration of developmental periods

65 (Dunlop et al. 2005). Such plastic changes in age and size at maturation are important when they

66 influence stock productivity or yield (Law and Grey 1989; Eikeset et al. 2013) and the resilience

67 of stocks to variation in harvest or other environmental conditions (Trippel 1995; Heino and

68 Godø 2002).

Density-dependent population regulation can strongly affect life history dynamics in

70 freshwater fish populations, including Great Lake stocks of yellow perch (Purchase et al. 2005a).

71 For example, Feiner et al. (2015) observed changes in life history traits related to changes in

72 level of harvest. Age and size at maturity increased in yellow perch stocks in Lake Huron and

73 Lake Michigan after the level of harvesting was reduced, but remained unchanged or slightly 
74 decreased in persistently harvested Lake Erie stocks (Feiner et al. 2015). However, the

75 mechanisms behind these changes are unknown because mean age and size at maturity were

76 averaged over a decade of cohorts and compared between decades. A finer temporal scale

77 analysis is required to understand whether harvest can drive changes in maturation over shorter

78 intervals in harvested fishes. This is especially true for species like yellow perch with a

79 generation time of less than 5 years. Analyses of freshwater fish stocks are also of value because most analyses to date have been for marine stocks, and there is uncertainty about whether

81 freshwater species responses are similar to what is observed in heavily exploited marine fisheries

82 (Dunlop et al. 2015). extent to which harvest contributes to phenotypic changes in a freshwater fishery. Yellow perch 85 are harvested commercially by gillnets and trap-nets and recreationally by hook and line, and these activities contribute considerable economic value to the Great Lakes region (Brenden et al.

87 2013). Yellow perch in Lake Erie have a generation time of three to four years and a long and variable history of commercial and recreational harvest (Baldwin et al. 2009). Furthermore, long term data are available from government agencies (Belore et al. 2016). Our assumption that

90 plastic responses in maturation can be driven by variation in growth rate is reasonable because

91 immature growth and maturation schedules vary within and among yellow perch cohorts

92 (Purchase et al. 2005a; Feiner et al. 2015). The general level of harvesting (harvest intensity 93 hereafter) has been high, but variable in Lake Erie. For example, one measure of fishing intensity 94 (instantaneous fishing mortality; F) from all forms of fishing declined from 2.37 year $^{-1}$ between $951975-1985$ to 0.91 year $^{-1}$ between $1985-1998$, and then to 0.33 year $^{-1}$ between $1998-2013$

96 (Fig. 2). The annual allowable catch of yellow perch (4.180 million kg for 2017) is set by the 
97 Lake Erie Commission (LEC) based on recommendations from the Lake Erie Standing

98 Committee and the Yellow Perch Task Group (Brenden et al. 2013). LEC apportions the

99 allowable catch to individual states and the province of Ontario based on proportions of lake

100 area. The Ontario Ministry of Natural Resources and Forestry (OMRNF) manages the Canadian

101 commercial fisheries through an individually transferable quota system begun in 1984 (Brenden

102 et al. 2013).

We empirically evaluated a conceptual model where individual juvenile life history responds plastically to the consequences of annual variation in the harvest of adult spawners

(Fig. 3). The model assumes an indirect effect of harvest on recruitment that subsequently affects juvenile survival, growth and maturity. The relationship between parental stock size and subsequent recruitment governs any effect of harvest on recruitment. We assume a Ricker stockrecruitment relationship for Lake Erie yellow perch because larger fish strongly cannibalize smaller perch (Knight et al. 1984). We further assume that, under current conditions, any change 110 in recruitment will be positively correlated with, or independent of, any change in stock size, 111 because stock size in the most heavily fished west basin of Lake Erie (MU1) has been low from 1121999 - 2013 (Zhang et al. 2017).

The plasticity model we evaluate assumes that a large harvest of adults reduces total 114 annual reproduction resulting in a reduced abundance of young of the year (YOY). We posit that 115 reduced abundance of YOY reduces intraspecific competition and increases the availability of 116 resources, and so increases individual growth rate. Rapidly growing individuals will then mature 117 at an earlier age (Policansky 1993; de Roos et al. 2006) and smaller size (Grift et al. 2003;

118 Dieckmann and Heino 2007; Thorpe 2007) several years after the direct effect of harvest on the 119 abundance of parents (Fig. 3). Our model predicts an indirect, negative correlation between 
120 annual harvest and annual estimates of age and length at 50\% maturity lagged over a 2-3 year

121 developmental period (Froese and Pauly 2016) following harvest. We also test a suite of

122 predicted relationships that comprise the causal chain leading to the predicted correlation

123 between harvest intensity and age and length at maturity to better understand the phenotypic

124 effects of harvest on yellow perch, which are currently unknown. Table 1 summarizes

125 predictions of the graphical model shown in Figure 3. Our analysis focuses on females because 126 of their larger impact on population dynamics through fecundity and potential maternal effects 127 relative to that of males.

\section{Methods}

For each yellow perch cohort from 1991-2013, our tests required estimates of age and

130 length at maturity, annual intensity of harvest, abundances of young of the year (YOY, age $0+$ ),

131 juveniles (age 1), and ages 2 and older fish, and estimates of growth in the first and second year

132 (Table 1). The Lake Erie yellow perch fishery consists of four main management units (MUs,

133 Fig. 1): MU1 (western basin), MU2 (west-central basin), MU3 (east-central basin including data

134 collected from sub-area Pennsylvania Ridge), and MU4 (eastern basin; data from subunit MU5

135 were sparse and were excluded). The estimates needed for our tests were calculated yearly for

136 the entire lake and for each management unit. We extracted data for annual cohorts

137 (corresponding to birth year) from the Lake Erie partnership index fishing survey database (a

138 gillnet survey independent of the fishery) maintained by the Lake Erie Management Unit

139 (Ontario Ministry of Natural Resources and Forestry 2016) and from the Yellow Perch Task

140 Group Report (Belore et al. 2014). 
Maturation is the process within an individual of allocating energy during development to

142

143

144

145

146

147

148

149

150

151

152

153

154 germinal tissue with the endpoint being the production of ripe gametes. In fish, this process starts soon after fertilization when gonadal tissue appears in the early embryo. Age and length at maturation are a result of this process (Thorpe 2007). In this study, it was not possible to determine age or length at maturation for individuals. We instead used an individual's maturity status at the time of capture as an indicator of when they matured. Maturity at the time of capture includes fish that could have matured in a previous year at a smaller length and age.

Consequently, estimates of age and length at maturity from capture samples are usually greater than the age and length at maturation. Age and length at maturity are commonly measured metrics in many fisheries studies, while age and length at maturation are much more difficult to measure. In our study of Lake Erie yellow perch, age and length at $50 \%$ maturity $\left(\mathrm{A}_{50}\right.$ and $\mathrm{L}_{50}$, respectively) and their $95 \%$ confidence intervals were estimated using logistic regression to estimate the probability of being mature (versus immature) in relation to length and age, and then using inverse prediction to estimate the length or age corresponding to a probability of maturity of 0.5 (Jørgensen 1990; O’Brien 1999). Age at maturity was increased by 1 year because maturity was assessed from fall samples whereas these yellow perch spawn in May (Purchase et al. 2005b). management unit were estimated using annual arithmetic mean catch of yellow perch per bottom gang (CPUE) from the Lake Erie partnership index fishing survey database (Table 2). The CPUE was calculated as the mean number of yellow perch per bottom gang in variable mesh size monofilament gill nets from the fisheries independent partnership survey (gillnets are composed of 25 panels of 13 different mesh sizes; 32, 38, 44, 51, 57, 64, 70, 76, 89, 102, 114, 127, 140, 152 
164 mm stretched measure; Ontario Ministry of Natural Resources and Forestry 2016). The index 165 gear may not fully sample all age 1 fish (especially smallest fish), but is believed to select all 166 lengths of ages 2 and older yellow perch (A. Cook, Ontario Ministry of Natural Resources and 167 Forestry, Wheatley, Ontario, personal communication, 2016). The number of gangs fished 168 annually from 1991 to 2013 varied from 58 to 144 with a mean of 125 . Detailed information on 169 the partnership index fishing sampling protocol, site selection, sex determination and aging is 170 available from OMRNF (OMRNF and OCFA 2016). Relative abundance of ages 2 and older and 171 juveniles were averaged across MUs to estimate mean relative abundance for the whole lake 172 (Table 2).

Abundance of YOY fish was estimated as the arithmetic mean density (catch per hectare)

174 based on fall trawl surveys conducted in each management unit in each year (Table S1). The 175 density of YOY for the whole lake was estimated as the mean density of YOY for the four MUs. 176 Data for CPUE and YOY density were ln transformed, while data for juvenile (age 1) fish were $177 \ln (\mathrm{CPUE}+1)$ transformed (Table 2$)$ to accommodate three years of sampling when no juvenile 178 fish were caught. Growth in the first year and second year was estimated for each cohort from the fisheryindependent partnership index fishing survey data. Growth in the first year was estimated as the 181 mean size of age 1 individuals. Growth in the second year was estimated as mean size increase 182 from age 1 to 2 (Table 2). The estimates of growth in the first year could be biased upwards, 183 because the smallest age 1 fish may not be captured in the index fishing gear. However, we 184 believe our estimate provides a reasonable index of first year growth because gear size was 185 standardized, so a larger range of sizes should be captured in years when growth rate is higher 
186 than in years when growth rate is lower. In addition, size at age 1 was positively correlated with

187 size at age $2(\mathrm{r}=0.62, p<0.002)$.

Three measures of harvest intensity were considered: the estimated biomass of fish

189 harvested from commercial and recreational fisheries divided by the CPUE of ages 2 and older

190 from the fishery-independent index survey (harvest ratio), the total biomass harvested divided by

191 biomass of ages 2 and older (exploitation ratio) estimated by the Yellow Perch Task Group, and

192 the instantaneous fishing mortality $\left(\mathrm{F}\right.$; year $\left.{ }^{-1}\right)$ estimated by the Yellow Perch Task Group. Three

193 measures were considered because quantifying harvest intensity is challenging when multiple

194 gear types are used to harvest a population and because different information and methods were

195 used to calculate each measure. Harvest ratio was estimated using fishery-independent index

196 survey data from Belore et al. (2014). Alternatively, estimates of the biomass of ages 2 and older

197 used to calculate exploitation ratio and instantaneous fishing mortality were made using a

198 statistical catch-at-age model (Brooks and Deroba 2015). For prediction B, interpretation of the

199 correlation between biomass of ages 2 and older fish and harvest ratio is complicated, because

200 harvest ratio is calculated using the biomass of ages 2 and older fish (a part-whole correlation;

201 Sokal and Rohlf 2012). This is not the case for equivalent tests involving exploitation ratio and

202 F. Conversely, values of exploitation ratio and $\mathrm{F}$ are based on models of population abundance

203 and biomass that include their own assumptions about observational, structural, and estimation

204 uncertainty (Brooks and Deroba 2015). No one measure is ideal because, although the three

205 measures of harvest intensity at the whole lake scale were positively and significantly correlated

206 with each other ( $\mathrm{r}$ values range from 0.63 to 0.90 , all $p$ 's $<0.002$, Table $\mathrm{S} 3$; values for the whole

207 lake were obtained by averaging values across the four MUs), the three measures varied in the 
208 magnitude of their coefficient of variation (Table S2 and S3). Thus we analyzed our model using $209 \ln$ transformed values of all three measures of harvest intensity.

211 summarized in Table 1 were tested assuming a generation time of 2 and 3 years (Froese and

212 Pauly 2016). We then relaxed the assumption of a 2-3 year lag time and used cross-correlation 213 analysis to explore relationships between harvesting and $\mathrm{L}_{50}$ and $\mathrm{A}_{50}$ over lag times up to 8 years

214 (2-3 generations). We did this to consider the possibility that maternal effects in yellow perch 215 (Andree et al. 2015) could extend maternal environmental influences across generations and to 216 account for any changes in maturation schedule due to fishing or other factors that could change 217 generation time in the population (Dunlop et al. 2009).

Prior to our analyses, the time series data were detrended and pre-whitened to minimize the possibility that changes occurring at multiple temporal scales would confound our cross220 correlation analyses. To achieve this, we first tested for a linear relationship between each 221 variable and time (year) and, if significant, detrended the variable using a linear regression 222 against time. The residuals were then used as the detrended variable. We then inspected the 223 partial and full autocorrelation of each variable (detrended or not) (Probst et al. 2012). When 224 evidence of autocorrelation was observed for a variable, an autoregressive integrative moving 225 average (ARIMA) model was used to reduce the chance of spurious correlations arising from 226 temporally adjacent values. Variables that were detrended and subjected to ARIMA modeling 227 are identified in Table 2. All analyses were conducted in R 3.0.2 (R Core Team 2014).

\section{Results}


Annual cohort estimates of $\mathrm{A}_{50}$ and $\mathrm{L}_{50}$ varied widely between 1991 and 2013 for the

230

231

232

233

234

235

236

237

238

239

240

241

242

243

244

245

246

247

248

249

250

251 whole lake (Fig. 4). Mean $\mathrm{A}_{50}$ ranged from 1.5 to 3.2 years for the whole lake (mean $=2.5$ years, $\mathrm{SD}=0.37$, Table 2$)$ and mean $\mathrm{L}_{50}$ ranged from $149 \mathrm{~mm}$ to $184 \mathrm{~mm}($ mean $=167 \mathrm{~mm}, \mathrm{SD}=9.82$, Table 2). Over this period, there was no evidence that either $\mathrm{A}_{50}$ or $\mathrm{L}_{50}$ changed in a consistent direction. $\mathrm{L}_{50}$ in particular declined from 1991 to 1996 (176 mm to $\left.149 \mathrm{~mm}\right)$, increased until $2004(183 \mathrm{~mm})$, then declined until 2009 (157 mm) before increasing again (Fig. 4). Similar trends were observed for all management units (Table 2, Fig. 4, panels C to I). Annual cohort means of $\mathrm{A}_{50}$ and $\mathrm{L}_{50}$ were positively correlated at both the whole lake $(\mathrm{r}=0.69, p<0.001$, Fig. 5) and the individual MU scales (MU1: $\mathrm{r}=0.75, p<0.0001$; MU2: $\mathrm{r}=0.56, p<0.01$; MU3: $\mathrm{r}=$ 0.73, $p<0.0001$; and MU4: $\mathrm{r}=0.70, p<0.001)$ (Fig. 5).

Overall, we found no consistent evidence to support our plastic life history model. The findings were generally not consistent with our first prediction that $\mathrm{A}_{50}$ and $\mathrm{L}_{50}$ in Lake Erie yellow perch would be negatively related to the harvest intensity 2-3 years earlier, although the degree of support differed depending on the measure of harvest intensity (Prediction A; Table 1, Fig. 3). When harvest ratio was considered, $\mathrm{L}_{50}$ did not decrease significantly two to three years after the year of harvest, both for tests at the whole lake level and for each management unit (Prediction A1; Table 1, Fig. 6, panels A and B). All correlations between harvest ratio and $\mathrm{L}_{50}$ two or three years later were negative but small for the whole lake and for individual MUs (Table 3). The same outcomes were observed for exploitation ratio (Table 3). Analyses considering $\mathrm{F}$ differed for prediction $\mathrm{A}$. Correlations between $\mathrm{F}$ and $\mathrm{L}_{50}$ were negative and statistically significant for a time lag of 3 years at the whole lake level and for MU1 and MU3 (Table 3), but not MU2 and MU4. Outcomes for analyses considering $\mathrm{A}_{50}$ instead of $\mathrm{L}_{50}$ (Prediction A2) were similar (Table 1). When considering harvest ratio, there was no evidence 
252 for a negative correlation with $\mathrm{A}_{50}$ at either the whole lake level or individual management units.

253 The same outcome was observed for exploitation ratio. For F, however, significant correlations 254 were observed between $\mathrm{F}$ and $\mathrm{A}_{50} 3$ years later for MU2 and MU4, but not for the whole lake or 255 MU1 and MU3. The MUs where significant correlations were observed between $\mathrm{F}$ and $\mathrm{A}_{50}$ were 256 not consistent with the MUs where correlations were observed between $\mathrm{F}$ and $\mathrm{L}_{50}$ (Table 3 ).

258 supported in analyses involving harvest ratio and exploitation ratio, but equivocal for analyses 259 involving F. The CPUE of ages 2 and older yellow perch in the year of harvest was negatively 260 related with harvest ratio at the whole lake (Fig. 6, panel C) and consistently for each of the MUs 261 (Table 3). CPUE of ages 2 and older in the year of harvest was also consistently and negatively 262 correlated with exploitation ratio in all cases (Table 3), suggesting the results for harvest ratio 263 were not a consequence of a part-whole correlation effects. Significant negative correlations 264 between $\mathrm{F}$ and the abundance of age 2 and older fish were only observed for MU1 and MU4, and 265 not for the whole lake or MU2 and MU3 (Table 3).

There was little evidence that the reductions in spawning abundance due to harvest had 267 any carryover effects on individual juvenile growth of the next generation. Densities of YOY in 268 the year after (or CPUE of age 1 fish two years later) were unrelated to CPUE of ages 2 and 269 older fish in the year of harvest, at the whole lake level (Fig. 6, panel D and E) or in the 270 individual MUs, except for MU1 where the significant negative correlation observed was counter 271 to what was predicted (Table 4, relationship C2). Immature fish did not grow significantly faster 272 at lower densities (Prediction D). The density of YOY fish was unrelated to growth rate in the 273 same year (size at age 1) both for the whole lake (Fig. 6, panel F) and for the MUs (Table 4). 274 CPUE of age 1 fish was also unrelated to growth in the $2^{\text {nd }}$ year (size increase from age 1 to age 
275 2; Fig. 6. Panel G, Table 4). With one exception involving MU1, using size at age 2 as a metric 276 of juvenile growth did not qualitatively change these results.

277 Similarly there was little evidence for any relationship between individual juvenile 278 growth and $\mathrm{A}_{50}$ and $\mathrm{L}_{50}$ (Prediction $\mathrm{E}$ ). $\mathrm{A}_{50}$ and $\mathrm{L}_{50}$ were not significantly correlated with size at 279 age 1 or the increase in size from age 1 to 2 at the whole lake level (Fig. 6, panel H, I) and for 280 each MU (Table 4). Using size at age 2 as a metric of juvenile growth did not change these 281 results with respect to $\mathrm{L}_{50}$ (whole lake and all MUs) or to $\mathrm{A}_{50}$ (whole lake and MUs 1 and 4, but 282 was negative in MUs 2 and 3).

Finally, there was no evidence for a relationship between harvesting and $\mathrm{A}_{50}$ or $\mathrm{L}_{50}$ at

284 time lags greater than 2-3 years. In cross-correlation analyses, $\mathrm{A}_{50}$ and $\mathrm{L}_{50}$ were unrelated to 285 harvest ratio at across lags of up to 8 years, for the whole lake and for each MU. The same 286 outcomes were obtained using the other two indices of harvest intensity.

\section{Discussion}

We found little evidence that annual changes in $\mathrm{A}_{50}$ and $\mathrm{L}_{50}$ for Lake Erie yellow perch 289 could be explained by changes in the intensity of commercial and recreational harvesting. $\mathrm{A}_{50}$ and $\mathrm{L}_{50}$ of yellow perch varied considerably over the 23 -year period. However, this variation was

291 generally unrelated to harvest 2 - 3 years before (Prediction A), as expected for plastic changes

292 in maturation to occur, although some support for harvest effects was observed when the

293 instantaneous fishing mortality was considered. We did find evidence that the abundance of 2

294 year and older fish was higher when measures of harvest intensity were lower (Prediction B: for

295 harvest and exploitation ratios but not for instantaneous fishing mortality). However the

296 abundances of YOY 1 year later and age 1 individuals 2 years later were unrelated to the 
297 abundance of 2 year and older fish in the spawning stock responsible for the cohort (Prediction

298 C). In addition, we found little evidence that juvenile growth rates responded to changes in 299 abundance (Prediction D) or that $\mathrm{A}_{50}$ and $\mathrm{L}_{50}$ responded to changes in juvenile growth rate 300 (Prediction E). In summary, we conclude that the changes in $\mathrm{A}_{50}$ and $\mathrm{L}_{50}$ cannot be explained by 301 plastic responses to harvest intensity during the time period considered because we were unable 302 to obtain consistent evidence for the overall relationship predicted between $\mathrm{A}_{50}$ and $\mathrm{L}_{50}$ and 303 measures of harvest intensity (Prediction A), and for key predicted relationships comprising the causal mechanism (Predictions $\mathrm{C}$ to $\mathrm{E}$, Tables 1 and 4).

Three features of the variation in $\mathrm{A}_{50}$ and $\mathrm{L}_{50}$ suggest it reflects the outcome of plastic responses in maturation. First, the highly polygenic nature of life history traits are expected to express more plasticity relative to other traits (Houle 1992), and genetic and environmental 308 effects on maturation can generate sizable variation in $\mathrm{A}_{50}$ and $\mathrm{L}_{50}$ between individuals within 309 and among populations (Bernardo 1993). In Lake Erie yellow perch, temporally-based 310 coefficients of variation $(\mathrm{CV})$ for $\mathrm{A}_{50}$ and $\mathrm{L}_{50}$ across annual cohorts were $14.8 \%$ and $5.8 \%$, 311 respectively. These values are similar in magnitude, although not directly comparable, to 312 spatially derived CV estimates of $23.8 \%$ and $16.6 \%$, respectively, across 72 inland Ontario 313 yellow perch populations (Purchase et al. 2005a; 2005b). Second, the direction of changes in 314 maturity characters reversed over only a few years. This variability is contrary to the steady 315 declines in $\mathrm{A}_{50}$ and $\mathrm{L}_{50}$ observed in many commercially harvested marine and freshwater fishes 316 (Trippel 1995; Olsen et al. 2004; Sharpe and Hendry 2009). Third, the rates of change in $\mathrm{A}_{50}$ and $317 \mathrm{~L}_{50}$ were also high when compared to rates observed in other commercially harvested fish. For 318 example, $\mathrm{A}_{50}$ and $\mathrm{L}_{50}$ in Lake Erie yellow perch cohorts declined at rates of -51.8 and -33.1

319 kilodarwin (-36\% and -18\% changes), respectively, from 1991 to 1996 (1991 - 1997 for $\mathrm{A}_{50}$ ), 
320 but then increased at rates of 231.2 and 62.7 kilodarwin (37.0\% and $17.1 \%$ changes),

321 respectively from 2001 to $2004\left(2002-2004\right.$ for $\left.\mathrm{A}_{50}\right)$. These rates of change are much faster

322 than the -19.4 and -17.2 kilodarwin declines (26.0\% and $20.0 \%$ changes), respectively, reported

323 for $\mathrm{A}_{50}$ and $\mathrm{L}_{50}$ in four marine fishes (Darimont et al. 2009) or the -10.5 and -10.3 kilodarwin

324 mean changes in $\mathrm{A}_{50}$ and $\mathrm{L}_{50}$ observed in other commercial fish stocks (Sharpe and Hendry

325 2009). Alternatively, the annual changes in $\mathrm{A}_{50}$ and $\mathrm{L}_{50}$ could reflect rapid, year-to-year changes

326 in harvest selectivity, but we know of no major changes in gear type and fishing operations

327 beyond harvest intensity over the study period. The annual changes in $\mathrm{A}_{50}$ and $\mathrm{L}_{50}$ could also

328 reflect annual variation in other sources of selection (e.g. natural predators) that influence

329 distributions of age and length among cohorts (discussed further below; Zhang et al. 2015).

Our conclusion that the fluctuations in $\mathrm{A}_{50}$ and $\mathrm{L}_{50}$ of Lake Erie yellow perch cannot be

explained by contemporary harvesting contrasts with the findings of an earlier study relating

332 maturation and harvest in the Great Lakes yellow perch. Feiner at al. (2015) tested for changes in

$333 \mathrm{~A}_{50}$ in stocks of yellow perch from Lakes Erie, Huron, and Michigan. They found that female

$334 \mathrm{~A}_{50}$ had increased in stocks where harvest was reduced, but had declined in the western Lake

335 Erie stock (MU1) where intensive commercial harvest was maintained. The difference between

336 studies may be due to differences in temporal scale of analysis. Feiner et al. (2015) used decadal

337 estimates of $\mathrm{A}_{50}$ compared across three sequential decades, whereas we analyzed annual cohort

338 estimates to understand whether harvest influenced dynamics on a finer time-scale.

It is valuable to consider why we did not observe declines in $\mathrm{A}_{50}$ and $\mathrm{L}_{50}$ with increasing harvest. We first consider the quality of the data and our modeling method before considering 341 other aspects of Lake Erie yellow perch. There is a possibility that we were unable to detect an effect of harvest on $\mathrm{A}_{50}$ and $\mathrm{L}_{50}$ because of the modest duration of the time series and number of 
343 cohorts available for analysis. However, we observed consistent support for the predicted 344 negative relationship between harvest intensity and spawning population abundance (Prediction 345 B) when considering harvest ratio and exploitation ratio, but not F. Interpretation of the analyses 346 involving $\mathrm{F}$ are complicated because its calculation is based on a statistical catch at age model 347 that requires modeled estimates of population abundance and biomass that generate uncertainty 348 in the harvest intensity. The consistent support for prediction B with at least two of the measures 349 of harvest intensity suggests that statistical power alone is an incomplete explanation for the 350 failure of the model. There is also the possibility that our data lacked sufficient variation in 351 harvest intensity to detect correlations using comparisons among cohorts. We consider this 352 unlikely. Coefficients of variation $(\mathrm{CVs})$ for our measures of harvest intensity for Lake Erie 353 yellow perch were comparable to CVs of 0.11 to 0.36 for measures of harvest intensity used in 354 analyses of four harvested marine fishes where fishing-induced evolution is suspected (Heino et 355 al. 2002; Pardoe et al. 2009; Marty et al. 2014; McAdam and Marshall 2014). Further, the 2-3 356 year generation time of yellow perch means that the 23 year time series is long enough that seven 357 complete generations of fish were exposed to harvest, allowing time for any effects of harvest to 358 manifest through all life stages multiple times.

We also explored whether Lake Erie yellow perch could have experienced different 360 population dynamical phases between 1991-2001, when $\mathrm{A}_{50}$ and $\mathrm{L}_{50}$ were declining, and 2002361 2013, when $\mathrm{A}_{50}$ and $\mathrm{L}_{50}$ were fluctuating over time. Tests of the plasticity model again provided 362 no consistent support for changes in $\mathrm{A}_{50}$ and $\mathrm{L}_{50}$ being due to contemporary harvest (Table $\mathrm{S} 4$ ). 363 During the period from 1991-2001, L50 was negatively and significantly correlated with harvest 364 ratio, but not exploitation ratio or F (Prediction A), and there was no support for density365 dependent responses in growth rate (Prediction D) or growth rate influencing $\mathrm{L}_{50}$ (Prediction E) 
366 (Table S5). There was also no significant negative correlation between $\mathrm{A}_{50}$ and the measures of

367 harvest intensity, and no significant correlations in support of density-dependent growth rates

368 and growth-dependent age at maturity (Table S5). Similarly, during the period from 2002-2013,

369 neither $\mathrm{A}_{50}$ nor $\mathrm{L}_{50}$ was negatively correlated with harvest ratio, exploitation rate, or $\mathrm{F}$, and there

370 was no support for density-dependent responses in growth rate (Prediction D) or for growth rate

371 influencing $\mathrm{L}_{50}$ (Table S5).

Conversely, there could be features of the Lake Erie yellow perch fishery that reduce the

373 likelihood of harvest affecting maturation in the way we expected. We assumed that in the face

374 of energy limits, variation in maturation would be predominantly determined by variation in

375 immature growth rate with faster growing juveniles maturing earlier and at smaller size than

376 slower growing juveniles (as could result from a positively sloped maturation reaction norm).

377 However, any plastic responses to harvest could be affected by additional factors, including the

378 shape of the maturation reaction norm (e.g., linear or non-linear; increasing or decreasing

379 maturation probability with age or size), variability of growth trajectories within the population,

380 the probabilistic nature of maturation, and size selectivity of harvest (see e.g., Heino and

381 Dieckmann 2008; Dunlop et al. 2009). Most probabilistic maturation reaction norms (PMRNs)

382 estimated for fishes to date have negative slopes, where slower growing individuals mature at

383 smaller sizes than faster growing individuals (Heino and Dieckmann 2008); however, PMRNs

384 with horizontal (e.g. Vainikka et al. 2009) and positive slopes (e.g. Dunlop et al. 2005) have also

385 been observed, complicating predictions. The lack of an effect of growth on $\mathrm{A}_{50}$ in our study,

386 however, suggests that a horizontal slope of the maturation reaction norm was not a primary

387 cause of our findings because this would reduce variation in $\mathrm{L}_{50}$, which is abundantly expressed

388 among annual cohorts here. Feiner et al. (2015) measured PMRNs for yellow perch in Lakes 
389 Erie, Huron and Michigan, pooling data by decade for three time periods; these tended to be 390 mostly flat to slightly negative for the three age classes of females considered. Estimates of 391 PMRNs at an annual cohort scale for the Lake Erie yellow perch could reveal further insights 392 into maturation dynamics and are a focus of future research.

Another possibility is that after at least a century of exploitation, the ability of Lake Erie yellow perch to respond to further harvest pressure has reached a limit. A recent model comparing Great Lakes yellow perch, Atlantic cod (Gadus morhua), and Great Lakes lake whitefish (Coregonus clupeiformis), predicted yellow perch to have the least capacity to evolve in response to harvest because of their high rates of natural mortality which likely already favoured early maturation (Dunlop et al. 2015). This early maturation could also limit the extent of maturation plasticity possible, especially given the seasonality of the Great Lakes. Over the last century, mean female length at maturity in Lake Erie yellow perch has declined from 210 $\mathrm{mm}$ in 1927-1937 (Jobes 1952) to $179 \mathrm{~mm}$ in 1960 - 1966 to $165 \mathrm{~mm}$ in 1990 - 1999 and 166 $\mathrm{mm}$ in 2000 - 2010. Although $\mathrm{L}_{50}$ varied from $150 \mathrm{~mm}$ to $185 \mathrm{~mm}$ across the period examined 403 here, we do not know how much size at maturity has varied annually among cohorts in the past. maturity suggests that other mechanisms may be missing from the plasticity model. Annual 406 abundances of spawning fish over the period we analyzed may have been in a range where 407 recruitment was independent of spawning stock size (Zhang et al. 2017), possibly accounting for 408 why abundances of YOY and juveniles were not significantly correlated with spawning stock 409 (Predictions $\mathrm{C} 1$ and $\mathrm{C} 2$ ), and limiting the opportunity for density-dependent responses in growth 410 rate and maturation. Density-dependent responses in juvenile growth, survival and maturation 411 occur in fishes, including other populations of yellow perch (Jansen 1996; Lorenzen and Enberg 
412 2002; Purchase et al. 2005a), but the lack of support for reduced growth in abundant cohorts

413 (Prediction D) suggests other factors may regulate growth in addition to or instead of

414 competition within cohorts (Purchase et al. 2005b). One possibility is that growth rates are

415 influenced more strongly by competition among rather than within cohorts. The 2003 cohort was

416 one of the largest cohorts in the recent history of Lake Erie yellow perch. Individuals from the

417 following 2004 cohort matured later and at larger sizes than those in the 2003 cohort.

418 Alternatively, growth rates may be suppressed by annual variation in predation risk. Stock-

419 recruitment analyses suggest that yearling walleye (Sander vitreus) may exert a strong top-down

420 effect on yellow perch recruitment in Lake Erie through predation on YOY (Zhang et al. 2015).

421 Lastly, a very real possibility is that environmental factors other than harvest could be

422 driving the rapid, large and reversible changes in maturity in Lake Erie yellow perch. Lake-wide

423 effects on energy availability may supersede density-dependent growth responses in yellow

424 perch (Purchase et al. 2005b). Lake Erie has experienced recent ecological disturbances that

425 could influence yellow perch maturation. The arrival of invasive dreissenid mussels (Dreissena

426 polymorpha and D. bugensis) and round goby (Neogobius melanostomus) have altered water

427 quality (Munawar et al. 2005; Bunnell et al. 2014), the behaviour and energetics of predator and

428 prey fishes (Stapanian et al. 2009), and the energy pathways within the lake (Vanderploeg et al.

429 2002; Hecky et al. 2004). In addition, yellow perch recruitment is also weaker following short,

430 warm winters than following cold winters (Farmer et al. 2015), which could induce annual

431 variation in growth rate and maturation as modeled here but independent of harvest.

432 Eutrophication can influence the life history and production of fishes (Arend et al. 2011) and has

433 emerged as a recent concern following large algal blooms in the lake (Michalak et al. 2013;

434 Scavia et al. 2014). Assessing the extent to which maturation has fluctuated synchronously 
435 among species would be one step toward understanding the role of lake-wide environmental 436 change in Lake Erie.

437 Age and length at maturity in Lake Erie yellow perch have fluctuated rapidly over the 438 past 23 cohorts potentially in response to annual variation in an unknown environmental factor 439 other than harvest intensity. This is in contrast to the pronounced and steady declines in age and 440 length at maturity observed in several harvested marine fish stocks (Trippel 1995; Darimont et 441 al. 2009; Sharpe and Hendry 2009). Our analysis focused on phenotypic change and did not 442 specify whether that change was the result of evolution, phenotypic plasticity, or some 443 combination of the two. The processes responsible for rapid changes in Lake Erie yellow perch 444 maturity remain undetermined, but contemporary harvest pressure can be excluded as a major 445 causal factor over the last several decades. Identifying the factors driving maturation dynamics 446 will be challenging given the multifarious ways in which the Lake Erie ecosystem is changing, 447 but this is important given the influence of maturation dynamics on the productive capacity of 448 this commercially important species. 


\section{Acknowledgements}

We thank Tom D. Nudds and Kevin McCann (University of Guelph), Kevin B. Reid (Ontario Commercial Fisheries Association), and two anonymous reviewers for their comments on earlier drafts. We thank the Lake Erie Management Unit (Ministry of Natural Resources and Forestry) for providing the database from the Partnership Index Gillnet Survey. This research was funded by a Natural Sciences and Engineering Research Council of Canada Strategic Networks grant to the Canadian Fisheries Research Network and a grant-in-aid of research from the Ontario Commercial Fisheries Association. Data for this research were provided under written agreement with the Lake Erie Committee of the Great Lakes Fishery Commission.

\section{References}

Alm, G. 1959. Connection between maturity, size, and age in fishes. Report No. 40, Institute of Freshwater Research, Drottningholm, 145 p.

Anderson, C., Hsieh, C., Sandin, S.A., Hewitt, R., Hollowed, A., Beddington, J.R., May, R.M., and Sugihara, G. 2008. Why fishing magnifies fluctuations in fish abundance. Nature 452: 835-839. doi: 10.1038/nature06851.

Andree, S.R., Feiner, Z.S., Bledsoe, J.W., Cragun, A.M., and Höök, T.O. 2015. Ontogenetic variability of maternal effects in an iteroparous fish. Ecol. Freshw. Fish 24: 384-396. doi: 10.1111/eff.12153.

Arend, K.K., Beletsky, D., Depinto, J. V., Ludsin, S.A., Roberts, J.J., Rucinski, D.K., Scavia, D., Schwab, D.J., and Höök, T.O. 2011. Seasonal and interannual effects of hypoxia on fish habitat quality in central Lake Erie. Freshw. Biol. 56: 366-383. doi: 10.1111/j.13652427.2010.02504.x. 
471 Baldwin, N.A., Saalfeld, R.W., Dochoda, M.R., Buettner, H.J., and Eshenroder, R.L. 2009.

472 Commercial fish production in the Great Lakes 1867 - 2006. Available from

473 http://www.glfc.org/databases/commercial/commerc.php. [accessed 3 February 2016].

474

475 476

477 478 479 480 481 482 483 484 485 486 487

488 489 490 491 492

Belore, M., Cook, A., Hartman, T., Hosack, M., Kayle, K., Knihht, C., Markham, J., Murray, C., Thomas, M., and Witzel, L. 2014. Report of the Lake Erie Yellow Perch Task Group. Ann Arbor, Mitchigan, USA.

Belore, M., Cook, H.A., Einhouse, D., Hartman, T., Kayle, K.A., Macdougall, T., Murray, C., Thomas, M. V., and Witzel, L. 2016. Report of the Lake Erie Yellow Perch Task Group. Ann Arbor, Mitchigan, USA.

Bernardo, J. 1993. Determinants of maturation in animals. Trends Ecol. Evol. 8: 166-173. doi: 10.1016/0169-5347(93)90142-C.

Brenden, T.O., Brown, R.W., Ebener, M.P., Reid, K., and Newcomb, T.J. 2013. Great Lakes commercial fisheries: Historical overview and prognosis for the future. In Great Lakes fisheries policy and management. Edited by W.W. Taylor, A.J. Lynch, and N.J. Leonard. Michigan State University Press, East Lansing. pp. 339-397.

Brooks, E.N., and Deroba, J.J. 2015. When "data" are not data: the pitfalls of post-hoc analyses that use stock assessment model output. Can. J. Fish Aquat. Sci. 72: 634-641. doi: 10.1139/cjfa-2014-0231.

Bunnell, D.B., Barbiero, R.P., Ludsin, S.A., Madenjian, C.P., Warren, G.J., Dolan, D.M., Brenden, T.O., Briland, R., Gorman, O.T., He, J.X., Johengen, T.H., Lantry, B.F., Lesht, B.M., Nalepa, T.F., Riley, S.C., Riseng, C.M., Treska, T.J., Tsehaye, I., Walsh, M.G., Warner, D.M., and Weidel, B.C. 2014. Changing ecosystem dynamics in the Laurentian 
Great Lakes: Bottom-up and top-down regulation. Bioscience 64: 26-39. doi: 10.1093/biosci/bit001.

495

496

497

498

499

500

501

502

503

504

505

506

507

508

509

510

511

512

513

Charnov, E.L., and Berrigan, D. 1990. Dimensionless numbers and life history evolution: age of maturity versus the adult lifespan. Evol. Ecol. 4: 273-275. doi: 10.1007/BF02285246.

Conover, D.O., Munch, S.B., and Arnott, S.A. 2009. Reversal of evolutionary downsizing caused by selective harvest of large fish. Proc. R. Soc. B Biol. Sci. 276: 2015-2020. doi: 10.1098/rspb.2009.0003.

Darimont, C.T., Carlson, S.M., Kinnison, M.T., Paquet, P.C., Reimchen, T.E., and Wilmers, C.C. 2009. Human predators outpace other agents of trait change in the wild. Proc. Natl. Acad. Sci. U. S. A. 106: 952-954. doi: 10.1073/pnas.0809235106.

Dieckmann, U., and Heino, M. 2007. Probabilistic maturation reaction norms: their history, strengths, and limitations. Mar. Ecol. Prog. Ser. 335: 253-269. doi: 10.3354/meps335253.

Dunlop, E.S., Eikeset, A.M., and Stenseth, N.C. 2015. From genes to populations: how fisheriesinduced evolution alters stock productivity. Ecol. Appl. 25: 1860-1868. doi: 10.1890/141862.1.

Dunlop, E.S., Heino, M., and Dieckmann, U. 2009. Eco-genetic modeling of contemporary lifehistory evolution. Ecol. Appl. 19: 1815-1834. doi: 10.1890/08-1404.1.

Dunlop, E.S., Shuter, B.J., and Ridgway, M.S. 2005. Isolating the influence of growth rate on maturation patterns in the smallmouth bass (Micropterus dolomieu). Can. J. Fish. Aquat. Sci. 62: 844-853. doi: 10.1139/F05-045.

Eikeset, A.M., Richter, A., Dunlop, E.S., Dieckmann, U., and Stenseth, N.C. 2013. Economic 
repercussions of fisheries-induced evolution. Proc. Natl. Acad. Sci. U. S. A. 110: 1225912264. doi: 10.1073/pnas.1212593110.

Enberg, K., Jørgensen, C., Dunlop, E.S., Heino, M., and Dieckmann, U. 2009. Implications of fisheries-induced evolution for stock rebuilding and recovery. Evol. Appl. 2: 394-414. doi: 10.1111/j.1752-4571.2009.00077.x.

Enberg, K., Jørgensen, C., Dunlop, E.S., Varpe, Ø., Boukal, D.S., Baulier, L., Eliassen, S., and Heino, M. 2012. Fishing-induced evolution of growth: concepts, mechanisms and the empirical evidence. Mar. Ecol. 33: 1-25. doi: 10.1111/j.1439-0485.2011.00460.x.

Engelhard, G.H., and Heino, M. 2004. Maturity changes in Norwegian spring-spawning herring before, during, and after a major population collapse. Fish. Res. 66: 299-310. doi: 10.1016/S0165-7836(03)00195-4.

Farmer, T.M., Marschall, E.A., Dabrowski, K., and Ludsin, S.A. 2015. Short winters threaten temperate fish populations. Nat. Commun. 6: 1-10. doi: 10.1038/ncomms8724.

Feiner, Z.S., Chong, S.C., Knight, C.T., Lauer, T.E., Thomas, M. V., Tyson, J.T., and Höök, T.O. 2015. Rapidly shifting maturation schedules following reduced commercial harvest in a freshwater fish. Evol. Appl. 8: 724-737. doi: 10.1111/eva.12285.

Froese, R., and Pauly, D. 2016. Fishbase. Available from www.fishbase.org [accessed 3 February 2016].

Grift, R.E., Rijnsdorp, A.D., Barot, S., Heino, M., and Dieckmann, U. 2003. Fisheries-induced trends in reaction norms for maturation in North Sea plaice. Mar. Ecol. Prog. Ser. 257: 247257. doi: $10.3354 /$ meps 257247 . 
Hard, J.J., Gross, M.R., Heino, M., Hilborn, R., Kope, R.G., Law, R., and Reynolds, J.D. 2008. Evolutionary consequences of fishing and their implications for salmon. Evol. Appl. 1: 388-408. doi: 10.1111/j.1752-4571.2008.00020.x.

Hecky, R.E., Smith, R.E.H., Barton, D.R., Guildford, S.J., Taylor, W.D., Charlton, M.N., and Howell, T. 2004. The nearshore phosphorus shunt: a consequence of ecosystem engineering by dreissenids in the Laurentian Great Lakes. Can. J. Fish. Aquat. Sci. 61: 1285-1293. doi: 10.1139/f04-065.

Heino, M., Baulier, L., Boukal, D.S., Dunlop, E.S., Eliassen, S., Enberg, K., Jørgensen, C., and Varpe, Ø. 2008. Evolution of growth in Gulf of St Lawerence cod? Proc. R. Soc. B Biol. Sci. 275: 1111-1112. doi: 10.1139/f02-014.

Heino, M., and Dieckmann, U. 2008. Detecting fisheries-induced life-history evolution: an overview of the reaction-norm approach. Bull. Mar. Sci. 83: 69-93.

Heino, M., Dieckmann, U., and Godo, O.R. 2002. Estimating reaction norms for age and size at maturation with reconstructed immature size distributions: a new technique illustrated by application to Northeast Arctic cod. ICES J. Mar. Sci. 59: 562-575. doi: 10.1006/jmsc.2002.1192.

Heino, M., and Godø, O.R. 2002. Fisheries-induced selection pressures in the context of sustainable fisheries. Bull. Mar. Sci. 70: 639-656.

Houle, D. 1992. Comparing evolvability and variability of quantitative traits. Genetics 130: 195204.

Jansen, W.A. 1996. Plasticity in maturity and fecundity of yellow perch, Perca flavescens (Mitchill): comparisons of stunted and normal-growing populations. Ann. Zool. Fennici 33: 

403-415.

558 559 560 561 562 563 564 565 566 567 568 569 570 571 572 573 574 575 576 577

Jobes, F.W. 1952. Age, growth, and production of yellow perch in Lake Erie. Fish. Bull. 52: 164.

Jørgensen, C., Enberg, K., Dunlop, E.S., Arlinghaus, R., Boukal, D.S., Brander, K., Ernande, B., Gardmark, A., Johnston, F., Matsumura, S., Pardoe, H., Raab, K., Silva, A., Vainikka, A., Dieckmann, U., Heino, M., and Rijnsdorp, A.D. 2007. Managing evolving fish stocks. Science. 318: 1247-1248. doi: 10.1126/science.1148089.

Jørgensen, T. 1990. Long-term changes in age at sexual maturity of Northeast Arctic cod (Gadus morhua L.). J. Cons. int. Explor. Mer. 46: 235-248. doi: 10.1093/icesjms/46.3.235.

Knight, R.L., Margraf, F.J., and Carline, R.F. 1984. Piscivory by walleyes and yellow perch in western Lake Erie. Trans. Am. Fish. Soc. 113: 667-693. doi: 10.1577/1548$8659(1984) 113<677$.

Kuparinen, A., Hardie, D.C., and Hutchings, J.A. 2011. Evolutionary and ecological feedbacks of the survival cost of reproduction. Evol. Appl. 5: 245-255. doi: 10.1111/j.17524571.2011.00215.x.

Kuparinen, A., and Merilä, J. 2007. Detecting and managing fisheries-induced evolution. Trends Ecol. Evol. 22: 652-659. doi: 10.1016/j.tree.2007.08.011.

Law, R., and Grey, D.R. 1989. Evolution of yields from populations with age-specific cropping. Evol. Ecol. 3: 343-359. doi: 10.1007/BF02285264.

Lorenzen, K., and Enberg, K. 2002. Density-dependent growth as a key mechanism in the regulation of fish populations: evidence from among-population comparisons. Proc. R. Soc. 
London. Ser. B Biol. Sci. 269: 49-54. doi: 10.1098/rspb.2001.1853.

579

580

581

582

583

584

585

586

587

588

589

590

591

592

593

594

595

596

597

598

599

Marty, L., Rochet, M.J., and Ernande, B. 2014. Temporal trends in age and size at maturation of four North Sea gadid species: Cod, haddock, whiting and Norway pout. Mar. Ecol. Prog. Ser. 497: 179-197. doi: 10.3354/meps10580.

McAdam, B.J., and Marshall, C.T. 2014. Bayesian fitting of probabilistic maturation reaction norms to population-level data. Fish. Res. 159: 105-113. doi: 10.1016/j.fishres.2014.05.014.

Michalak, A.M., Anderson, E.J., Beletsky, D., Boland, S., Bosch, N.S., Bridgeman, T.B., Chaffin, J.D., Cho, K., Confesor, R., Daloglu, I., Depinto, J. V, Evans, M.A., Fahnenstiel, G.L., He, L., Ho, J.C., Jenkins, L., Johengen, T.H., Kuo, K.C., Laporte, E., Liu, X., McWilliams, M.R., Moore, M.R., Posselt, D.J., Richards, R.P., Scavia, D., Steiner, A.L., Verhamme, E., Wright, D.M., and Zagorski, M.A. 2013. Record-setting algal bloom in Lake Erie caused by agricultural and meteorological trends consistent with expected future conditions. Proc. Natl. Acad. Sci. U. S. A. 110: 6448-6452. doi: 10.1073/pnas.1216006110.

Munawar, M., Munawar, I.F., Mandrak, N.E., Fitzpatrick, M., Dermott, R., and Leach, J. 2005. An overview of the impact of non-indigenous species on the food web integrity of North American Great Lakes: Lake Erie example. Aquat. Ecosyst. Health Manag. 8: 375-395. doi: 10.1080/14634980500411606.

Nusslé, S., Bornand, C.N., and Wedekind, C. 2009. Fishery-induced selection on an Alpine whitefish: quantifying genetic and environmental effects on individual growth rate. Evol. Appl. 2: 200-208. doi: 10.1111/j.1752-4571.2008.00054.x.

O’Brien, L. 1999. Factors influencing the rate of sexual maturity and the effect on spawning 
600

601

602

603

604

605

606

607

608

609

610

611

612

613

614

615

616

617

618

619

620

621

stock for Georges Bank and Gulf of Maine Atlantic cod Gadus morhua stocks. J. Northwest Atl. Fish. Sci. 25: 179-203. doi: 10.2960/J.v25.a17.

Olsen, E.M., Heino, M., Lilly, G.R., Morgan, M.J., Brattey, J., Ernande, B., and Dieckmann, U. 2004. Maturation trends indicative of rapid evolution preceded the collapse of northern cod. Nature 428: 932-935. doi: 10.1038/nature02453.1.

OMRNF and OCFA. 2016. 2016 Lake Erie partnership index fishing, project description and sampling protocol. Ontario Ministry of Natural Resources and Forestry.

Ontario Ministry of Natural Resources and Forestry, (OMNRF). 2016. 2015 Status of Major Stocks. Ontario Ministry of Natural Resources and Fortestry.

Pardoe, H., Vainikka, A., Thórdarson, G., Marteinsdóttir, G., and Heino, M. 2009. Temporal trends in probabilistic maturation reaction norms and growth of Atlantic cod (Gadus morhua) on the Icelandic shelf. Can. J. Fish. Aquat. Sci. 66: 1719-1733. doi: 10.1139/F09132.

Pinsky, M.L., and Palumbi, S.R. 2014. Meta-analysis reveals lower genetic diversity in overfished populations. Mol. Ecol. 23: 29-39. doi: 10.1111/mec.12509.

Policansky, D. 1993. Fishing as a cause of evolution in fishes. In Exploitation of Living Resources. Edited by K. Stokes, J.M. McGlade, and R. Law. Lecture Notes in Biomathematics, vol 99. Springer, Berlin, Heidelberg. pp. 8-18. doi: 10.1007/978-3-64248394-3_1.

Probst, W.N., Stelzenmu, V., and Fock, H.O. 2012. Using cross-correlations to assess the relationship between time-lagged pressure and state indicators: an exemplary analysis of North Sea fish population indicators. ICES J. Mar. Sci. 69: 670-681. doi: 
622

623

624

625

626

627

628

629

630

631

632

633

634

635

636

637

638

639

640

641

642

643

10.1093/icesjms/fss015.

Purchase, C.F., Collins, N.C., Morgan, G.E., and Shuter, B.J. 2005a. Sex-specific covariation among life-history traits of yellow perch (Perca flavescens). Evol. Ecol. Res. 7: 549-566.

Purchase, C.F., Collins, N.C., Morgan, G.E., and Shuter, B.J. 2005b. Predicting life history traits of yellow perch from environmental characteristics of lakes. Trans. Am. Fish. Soc. 134: 1369-1381. doi: 10.1577/T04-182.1.

R Core Team. 2014. R: A Language and Environment for Statistical Computing. R Foundation for Statistical Computing, Vienna, Austria.

Rochet, M.-J. 1998. Short-term effects of fishing on life history traits of fishes. ICES J. Mar. Sci. 55: 371-391. doi: 10.1006/jmsc.1997.0324.

de Roos, A.M., Boukal, D.S., and Persson, L. 2006. Evolutionary regime shifts in age and size at maturation of exploited fish stocks. Proc. R. Soc. London. Ser. B Biol. Sci. 273: 1873-80. doi: $10.1098 / \mathrm{rspb} .2006 .3518$.

Scavia, D., Allan, David, J., Arend, K.K., Bartell, S., Beletsky, D., Bosch, N.S., Brandt, S.B., Briland, R.D., Daloğlu, I., DePinto, J. V., Dolan, D.M., Evans, M.A., Farmer, T.M., Goto, D., Han, H., Höök, T.O., Knight, R., Ludsin, S.A., Mason, D., Michalak, A.M., Peter Richards, R., Roberts, J.J., Rucinski, D.K., Rutherford, E., Schwab, D.J., Sesterhenn, T.M., Zhang, H., and Zhou, Y. 2014. Assessing and addressing the re-eutrophication of Lake Erie: Central basin hypoxia. J. Great Lakes Res. 40: 226-246. doi: 10.1016/j.jglr.2014.02.004.

Sharpe, D.M.T., and Hendry, A.P. 2009. Life history change in commercially exploited fish stocks: an analysis of trends across studies. Evol. Appl. 2: 260-275. doi: 10.1111/j.17524571.2009.00080.x. 
644 Sokal, R.R., and Rohlf, F.J. 2012. Biometry: The principles and Practices of Statistics in 645 Biological Research. In 4th edition. W. H. Freeman and Co., New York.

646 Stapanian, M.A., Kocovsky, P.M., and Adams, J. V. 2009. Change in diel catchability of young647 of-year yellow perch associated with establishment of dreissenid mussels. Freshw. Biol. 54: 648 649 650 651 652 653 654 655 656 657 658 659 660 661 662 663

Vainikka, A., Mollet, F., Casini, M., and Gårdmark, A. 2009. Spatial variation in growth, Trippel, E.A. 1995. Age at maturity as a stress indicator in Fisheries. Bioscience 45: 759-771. doi: $10.2307 / 1312628$.

Thorpe, J.E. 2007. Maturation responses of salmonids to changing developmental opportunities. Mar. Ecol. Prog. Ser. 335: 285-288. doi: 10.3354/meps335285.

Stearns, S.C. 1992. The evolution of life histories. Oxford University Press, London.

651
1593-1604. doi: 10.1111/j.1365-2427.2009.02186.x. condition and maturation reaction norms of the Baltic herring Clupea harengus membras. Mar. Ecol. Prog. Ser. 383: 285-294. doi: 10.3354/meps07970.

Vanderploeg, H.A., Nalepa, T.F., Jude, D.J., Mills, E.L., Holeck, K.T., Liebig, J.R., Grigorovich, I.A., and Ojaveer, H. 2002. Dispersal and emerging ecological impacts of Ponto-Caspian species in the Laurentian Great Lakes. Can. J. Fish. Aquat. Sci. 59: 1209-1228. doi: 10.1139/f02-087.

Zhang, F., Reid, K.B., and Nudds, T.D. 2015. Counterintuitive patterns of spawning stock age structure and recruitment in Lake Erie yellow perch (Perca flavescens). Can. J. Fish Aquat. Sci. 1502: 1494-1502. doi: 10.1139/cjfas-2014-0489.

664 Zhang, F., Reid, K.B., and Nudds, T.D. 2017. Relative effects of biotic and abiotic factors during 

early life history on recruitment dynamics: a case study. Can. J. Fish. Aquat. Sci. doi:

666 10.1139/cjfas-2016-0155.

667 


\section{Tables}

669 Table 1. Prediction matrix of the relationships in Fig. 3 for the effect of: A) Harvest ratio,

670 measured as $\ln$ (Total catch in millions of $\mathrm{kg} / \mathrm{CPUE}$ of ages 2 and older), on female $\mathrm{A}_{50}$ or $\mathrm{L}_{50} 2$

671 and 3 years later; B) Harvest ratio on CPUE of ages 2 and older in the year of harvesting; C1-C2)

672 Abundance of ages 2 and older on density of YOY in the next year (1 year lag) and on the CPUE

673 of age 1 (2 year lag); D1-D2) YOY density on $1^{\text {st }}$ year growth (mean female size at age 1) and

674 CPUE of age 1 year fish on $2^{\text {nd }}$ year growth (mean female size increase from age $1-2$ ); E1-E2)

675 Early female growth in $1^{\text {st }}$ year and in $2^{\text {nd }}$ year on female length or age at $50 \%$ maturity ( 1 year

676 lag and no lag). Test outcomes were determined using Pearson's product moment correlation

677 coefficient (r) at $\alpha=0.05$. 


\begin{tabular}{|c|c|c|c|c|}
\hline $\begin{array}{l}\text { Predictions } \\
\text { from Fig. } 3\end{array}$ & Independent variable & Dependent variable & $\begin{array}{l}\text { Direction of predicted } \\
\text { relationship }\end{array}$ & Test Outcome \\
\hline A & Harvest ratio $(\mathrm{t} 0)^{*}$ & q $\mathrm{L}_{50}, \mathrm{~A}_{50}(\mathrm{t} 2 \& \mathrm{t} 3)$ & Negative & Not supported \\
\hline B & Harvest ratio (t0) & CPUE ages $2 \&$ older $(\mathrm{t} 0)$ & Negative & Supported \\
\hline $\mathrm{C} 1$ & CPUE ages $2 \&$ older (t0) & Density YOY (t1) & Positive/no relationship & Supported \\
\hline $\mathrm{C} 2$ & CPUE ages $2 \&$ older (t0) & CPUE age $1(\mathrm{t} 2)$ & Positive/no relationship & Supported \\
\hline D1 & Density YOY (t0) & $q$ Growth in $1^{\text {st }}$ year $(\mathrm{t} 0)$ & Negative & Not supported \\
\hline $\mathrm{D} 2$ & CPUE age $1(\mathrm{t} 0)$ & $q$ Growth in $2^{\text {th }}$ year $(t 0)$ & Negative & Not supported \\
\hline E1 & $q$ Growth in $1^{\text {st }}$ year (t0) & $q \mathrm{~L}_{50}, \mathrm{~A}_{50}(\mathrm{t} 1)$ & Negative & Not supported \\
\hline E2 & $q$ Growth in $2^{\text {th }}$ year $(\mathrm{t} 0)$ & $q \mathrm{~L}_{50}, \mathrm{~A}_{50}(\mathrm{t} 0)$ & Negative & Not supported \\
\hline
\end{tabular}

$679 *$ tn indicates the variable was lagged $\mathrm{n}$ years in the analysis, e.g. in prediction $\mathrm{A}$ harvest ratio in the year it was measured (t0) was

680 related to length at maturity two ( $\mathrm{t} 2)$ and three ( $\mathrm{t} 3)$ years later. 
681 Table 2. Summary statistics of the variables used to test the model in Figure 3, including number 682 of years of data available (N), minimum (Min), maximum (Max) and mean values (Mean), the 683 coefficient of variation (CV), and whether prior to cross correlation analysis the variable was 684 detrended (DT) and pre-whitened using an ARIMA model. $\mathrm{L}_{50}$, growth in first year and second 685 year are in $\mathrm{mm}, \mathrm{A}_{50}$ is in years, harvest ratio is million $\mathrm{kg} /$ mean catch per bottom gang ages 2 686 and older, CPUE ages 2 and older and CPUE age 1 is the mean number of yellow perch catch per 687 bottom net set, density YOY is number per hectare. The variables are summarized for data 688 aggregated across the lake and for each of four management units (MUs). 


\begin{tabular}{|c|c|c|c|c|c|c|c|c|}
\hline Area & Variable & $\mathrm{N}$ & Min & Max & Mean & $\mathrm{CV}$ & $\mathrm{DT}$ & ARIMA \\
\hline Whole & $q \mathrm{~A}_{50}$ & 23 & 1.5 & 3.2 & 2.5 & 0.15 & $\mathrm{~N}$ & $\mathrm{AM}(1)$ \\
\hline \multirow[t]{7}{*}{ Lake } & $q \mathrm{~L}_{50}$ & 23 & 149 & 184 & 167 & 0.06 & $\mathrm{~N}$ & $\operatorname{AR}(1)$ \\
\hline & $\ln$ (Harvest ratio) & 23 & 2.4 & 4.6 & 3.1 & 0.20 & $\mathrm{Y}$ & $\mathrm{AR}(1)$ \\
\hline & $\ln (\mathrm{CPUE}$ ages $2 \&$ older $)$ & 23 & 3.2 & 5.9 & 5.0 & 0.15 & $\mathrm{Y}$ & $\operatorname{AR}(1)$ \\
\hline & $\ln ($ Density YOY) & 23 & 1.6 & 6.0 & 4.1 & 0.27 & $\mathrm{~N}$ & $\mathrm{AR}(1)$ \\
\hline & $\ln ($ CPUE age $1+1)$ & 23 & 0.7 & 6.2 & 4.1 & 0.33 & $\mathrm{~N}$ & $\operatorname{AR}(1)$ \\
\hline & o Growth in 1 st year & 23 & 132 & 156 & 143 & 0.04 & $\mathrm{~N}$ & \\
\hline & o Growth in 2 th year & 23 & 29 & 64 & 48 & 0.16 & $\mathrm{~N}$ & \\
\hline \multirow[t]{7}{*}{ MU1 } & q $\mathrm{A}_{50}$ & 23 & 0.2 & 3.1 & 2.5 & 0.25 & $\mathrm{~N}$ & \\
\hline & ○ $\mathrm{L}_{50}$ & 23 & 138 & 187 & 167 & 0.07 & $\mathrm{~N}$ & $\operatorname{AR}(1)$ \\
\hline & $\ln$ (Harvest ratio) & 23 & 0.4 & 2.6 & 1.6 & 0.32 & $\mathrm{~N}$ & \\
\hline & $\ln (\mathrm{CPUE}$ ages $2 \&$ older $)$ & 23 & 3.9 & 6.3 & 5.1 & 0.11 & $\mathrm{~N}$ & $\operatorname{AR}(1)$ \\
\hline & $\ln ($ Density YOY) & 23 & 2.2 & 7.0 & 4.6 & 0.27 & $\mathrm{~N}$ & \\
\hline & $\ln ($ CPUE age $1+1)$ & 23 & 0 & 6.89 & 4.4 & 0.37 & $\mathrm{~N}$ & \\
\hline & o Growth in 1st year & 22 & 131 & 158 & 143 & 0.05 & $\mathrm{~N}$ & \\
\hline
\end{tabular}




\begin{tabular}{|c|c|c|c|c|c|c|c|c|}
\hline & $q$ Growth in 2 th year & 22 & 15 & 55 & 43 & 0.21 & $\mathrm{~N}$ & \\
\hline \multirow[t]{8}{*}{ MU2 } & $q \mathrm{~A}_{50}$ & 23 & 1.4 & 3.1 & 3.0 & 0.17 & $\mathrm{~N}$ & $\mathrm{AR}(1)$ \\
\hline & o $\mathrm{L}_{50}$ & 23 & 149 & 178 & 164 & 0.05 & $\mathrm{~N}$ & $\operatorname{MA}(1)$ \\
\hline & $\ln ($ Harvest ratio) & 23 & 1.4 & 4.4 & 2.4 & 0.28 & $\mathrm{Y}$ & $\mathrm{AR}(1)$ \\
\hline & $\ln$ (CPUE ages 2 and older) & 23 & 2.6 & 6.2 & 4.9 & 0.17 & $\mathrm{Y}$ & $\mathrm{AR}(1)$ \\
\hline & ln(Density YOY) & 23 & 0.5 & 5.0 & 3.1 & 0.43 & $\mathrm{~N}$ & $\operatorname{AR}(1)$ \\
\hline & $\ln ($ CPUE age $1+1)$ & 23 & 1.2 & 5.9 & 4.0 & 0.38 & $\mathrm{~N}$ & $\mathrm{AR}(1)$ \\
\hline & o Growth in 1st year & 23 & 134 & 176 & 147 & 0.07 & $\mathrm{~N}$ & \\
\hline & $q$ Growth in 2 th year & 23 & 28 & 69 & 49 & 0.23 & $\mathrm{Y}$ & $\operatorname{AR}(1)$ \\
\hline \multirow[t]{7}{*}{ MU3 } & $+\mathrm{A}_{50}$ & 23 & 1.6 & 3.4 & 2.6 & 0.19 & $\mathrm{~N}$ & \\
\hline & $q \mathrm{~L}_{50}$ & 23 & 145 & 184 & 167 & 0.06 & $\mathrm{~N}$ & $\operatorname{AR}(1)$ \\
\hline & $\ln ($ Harvest ratio) & 20 & -0.3 & 3.1 & 0.9 & 0.92 & $\mathrm{Y}$ & $\mathrm{AR}(1)$ \\
\hline & $\ln (\mathrm{CPUE}$ ages $2 \&$ older) & 20 & 3.4 & 7.1 & 5.9 & 0.19 & $\mathrm{Y}$ & $\operatorname{AR}(1)$ \\
\hline & ln(Density YOY) & 23 & -0.7 & 5.2 & 2.8 & 0.61 & $\mathrm{~N}$ & $\operatorname{AR}(1)$ \\
\hline & $\ln ($ CPUE age $1+1)$ & 20 & 0 & 6.2 & 3.0 & 0.66 & $\mathrm{~N}$ & \\
\hline & q Growth in 1 st year & 22 & 127 & 152 & 139 & 0.05 & $\mathrm{~N}$ & $\mathrm{MA}(1)$ \\
\hline
\end{tabular}




\begin{tabular}{|c|c|c|c|c|c|c|c|c|}
\hline & o Growth in 2 th year & 21 & 23 & 64 & 42 & 0.26 & Y & $\operatorname{AR}(1)$ \\
\hline \multirow[t]{8}{*}{ MU4 } & $q \mathrm{~A}_{50}$ & 20 & 1.9 & 3.5 & 2.7 & 0.15 & $\mathrm{~N}$ & \\
\hline & $q \mathrm{~L}_{50}$ & 21 & 119 & 207 & 171 & 0.14 & $\mathrm{~N}$ & MA(1) \\
\hline & $\ln$ (Harvest ratio) & 21 & -1.5 & 3.6 & 0.6 & 1.87 & $\mathrm{~N}$ & $\mathrm{AR}(2)$ \\
\hline & $\ln ($ CPUE ages $2 \&$ older $)$ & 21 & -0.2 & 5.6 & 3.7 & 0.39 & $\mathrm{Y}$ & $\operatorname{MA}(1)$ \\
\hline & $\ln ($ Density YOY) & 23 & -0.8 & 5.9 & 3.5 & 0.5 & $\mathrm{~N}$ & $\operatorname{AR}(1)$ \\
\hline & $\ln ($ CPUE age $1+1)$ & 21 & 0 & 4.9 & 3.7 & 0.58 & Y & \\
\hline & $q$ Growth in 1st year & 18 & 126 & 172 & 141 & 0.07 & $\mathrm{~N}$ & \\
\hline & $q$ Growth in 2 th year & 17 & 30 & 75 & 55 & 0.18 & $\mathrm{~N}$ & $\operatorname{MA}(1)$ \\
\hline
\end{tabular}


690 Table 3. Pearson correlation coefficients (r) obtained for tests of model predictions A1, A2 and B (Table 1, Figure 3) for three

691 measures of harvest intensity: harvest ratio, exploitation ratio, and instantaneous fishing mortality per year (F). A1) Harvest ratio and

692 female $\mathrm{L}_{50}$; A2) Harvest ratio and female $\mathrm{A}_{50}$; $\mathrm{B}$ ) harvest ratio and CPUE of ages 2 and older. Lag times t0, t2, and $\mathrm{t} 3$ refer to the time

in years between the dependent and independent variables. Correlation coefficients were estimated for the whole lake and for each of

694 four management units (MU). Values in bold are statistically significant at $p<0.05$.

695

\begin{tabular}{|c|c|c|c|c|c|c|c|}
\hline \multirow[b]{2}{*}{ Area } & \multirow[b]{2}{*}{$\begin{array}{l}\text { Pre- } \\
\text { diction }\end{array}$} & \multirow[b]{2}{*}{$\begin{array}{l}\text { Independent } \\
\text { variable }\end{array}$} & \multirow[b]{2}{*}{$\begin{array}{l}\text { Dependent } \\
\text { variable }\end{array}$} & & \multicolumn{3}{|c|}{ Harvest intensity indices } \\
\hline & & & & & $\begin{array}{c}\text { Harvest } \\
\text { ratio }\end{array}$ & $\begin{array}{l}\text { Exploitation } \\
\text { ratio }\end{array}$ & $\begin{array}{c}\mathrm{F} \\
\text { Year }^{-1}\end{array}$ \\
\hline \multirow[t]{9}{*}{ Whole Lake } & A1 & Harvest (t0)* & q $\mathrm{L}_{50}(\mathrm{t} 2)$ & $\mathrm{r}$ & 0.1 & 0.05 & 0.09 \\
\hline & & & & $p$ & 0.67 & 0.58 & 0.65 \\
\hline & & & & $\mathrm{df}$ & 19 & 19 & 19 \\
\hline & & Harvest (t0) & $+\mathrm{L}_{50}(\mathrm{t} 3)$ & $\mathrm{r}$ & -0.02 & -0.03 & -0.6 \\
\hline & & & & $p$ & 0.47 & 0.45 & 0.002 \\
\hline & & & & df & 18 & 18 & 18 \\
\hline & $\mathrm{A} 2$ & Harvest (t0) & $+\mathrm{A}_{50}(\mathrm{t} 2)$ & $\mathrm{r}$ & 0.31 & 0.16 & 0.22 \\
\hline & & & & $p$ & 0.92 & 0.75 & 0.83 \\
\hline & & & & $\mathrm{df}$ & 19 & 19 & 19 \\
\hline
\end{tabular}




\begin{tabular}{|c|c|c|c|c|c|c|}
\hline & Harvest (t0) & ㅇ $\mathrm{A}_{50}(\mathrm{t} 3)$ & $\mathrm{r}$ & -0.04 & -0.12 & -0.18 \\
\hline & & & $p$ & 0.44 & 0.31 & 0.23 \\
\hline & & & $\mathrm{df}$ & 18 & 18 & 18 \\
\hline B & Harvest (t0) & CPUE ages $2 \&$ older $(\mathrm{t} 0)$ & $\mathrm{r}$ & -0.96 & -0.64 & -0.26 \\
\hline & & & $p$ & $<0.0001$ & 0.0005 & 0.12 \\
\hline & & & $\mathrm{df}$ & 21 & 21 & 21 \\
\hline MU1 & Harvest (t0) & $q \mathrm{~L}_{50}(\mathrm{t} 2)$ & $\mathrm{r}$ & -0.1 & -0.09 & -0.03 \\
\hline & & & $p$ & 0.34 & 0.34 & 0.45 \\
\hline & & & $\mathrm{df}$ & 19 & 19 & 19 \\
\hline & Harvest (t0) & $q \mathrm{~L}_{50}(\mathrm{t} 3)$ & $\mathrm{r}$ & -0.2 & -0.21 & -0.56 \\
\hline & & & $p$ & 0.2 & 0.2 & 0.005 \\
\hline & & & df & 18 & 2118 & 18 \\
\hline $\mathrm{A} 2$ & Harvest (t0) & q $\mathrm{A}_{50}(\mathrm{t} 2)$ & $\mathrm{r}$ & 0.01 & 0.17 & 0.31 \\
\hline & & & $p$ & 0.52 & 0.77 & 0.92 \\
\hline & & & df & 19 & 19 & 19 \\
\hline & Harvest (t0) & $q \mathrm{~A}_{50}(\mathrm{t} 3)$ & $\mathrm{r}$ & -0.13 & -0.12 & -0.15 \\
\hline & & & $p$ & 0.30 & 0.3 & 0.26 \\
\hline & & & $\mathrm{df}$ & 18 & 18 & 18 \\
\hline
\end{tabular}




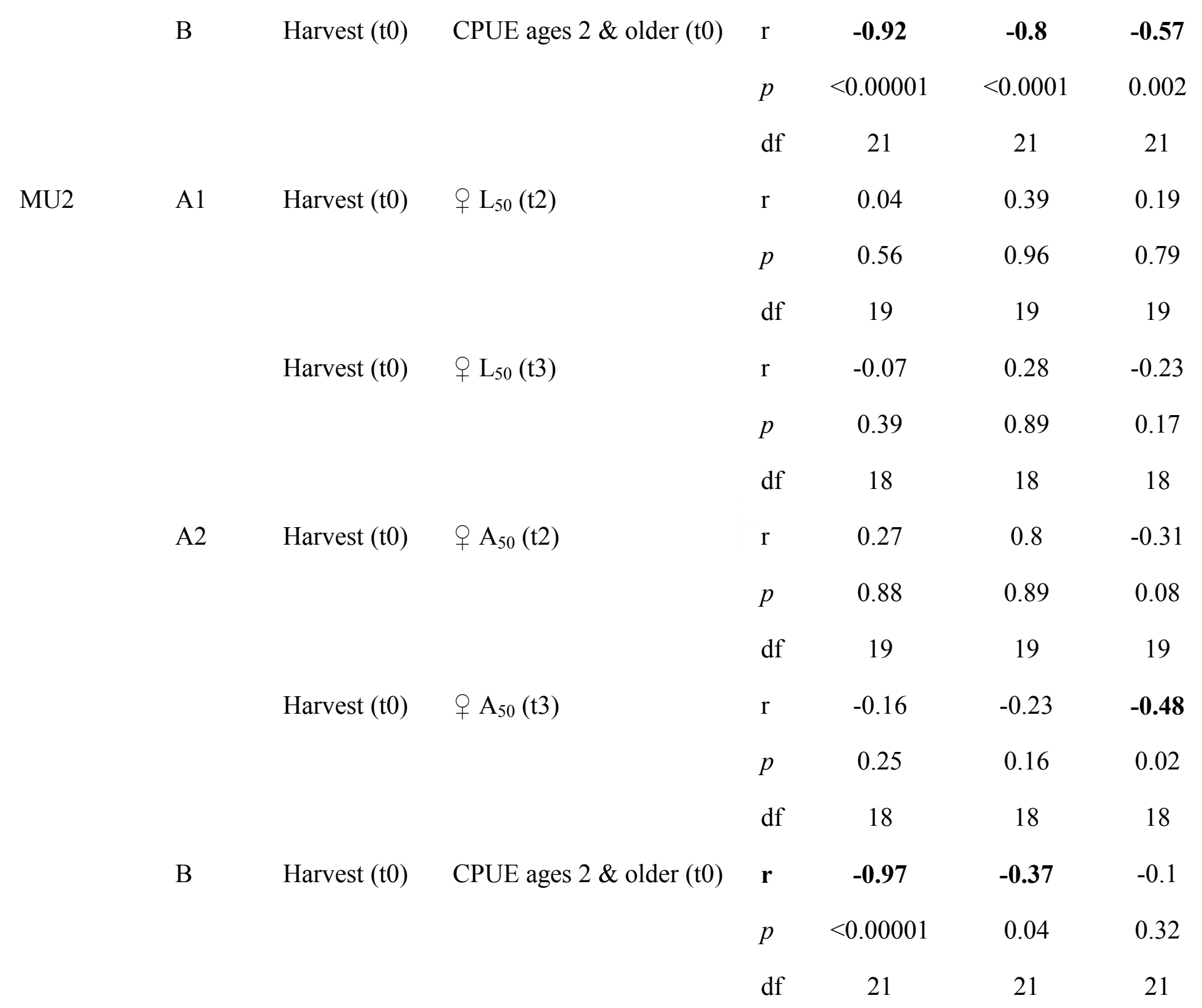




\begin{tabular}{|c|c|c|c|c|c|c|c|}
\hline \multirow[t]{13}{*}{ MU3 } & \multirow[t]{6}{*}{ A1 } & \multirow[t]{3}{*}{ Harvest (t0) } & \multirow[t]{3}{*}{ ○ $\mathrm{L}_{50}(\mathrm{t} 2)$} & $\mathrm{r}$ & 0.12 & 0.12 & -0.02 \\
\hline & & & & $p$ & 0.7 & 0.69 & 0.47 \\
\hline & & & & $\mathrm{df}$ & 17 & 19 & 19 \\
\hline & & \multirow[t]{3}{*}{ Harvest (t0) } & \multirow[t]{3}{*}{ q $\mathrm{L}_{50}(\mathrm{t} 3)$} & $\mathrm{r}$ & -0.19 & -0.18 & -0.55 \\
\hline & & & & $p$ & 0.23 & 0.23 & 0.006 \\
\hline & & & & $\mathrm{df}$ & 16 & 18 & 18 \\
\hline & \multirow[t]{6}{*}{$\mathrm{A} 2$} & \multirow[t]{3}{*}{ Harvest (t0) } & \multirow[t]{3}{*}{$+\mathrm{A}_{50}(\mathrm{t} 2)$} & $\mathrm{r}$ & 0.38 & 0.43 & 0.2 \\
\hline & & & & $p$ & 0.94 & 0.97 & 0.81 \\
\hline & & & & $\mathrm{df}$ & 17 & 19 & 19 \\
\hline & & \multirow[t]{3}{*}{ Harvest (t0) } & \multirow[t]{3}{*}{ q $\mathrm{A}_{50}(\mathrm{t} 3)$} & $\mathrm{r}$ & -0.12 & -0.18 & -0.16 \\
\hline & & & & $p$ & 0.32 & 0.22 & 0.25 \\
\hline & & & & $\mathrm{df}$ & 16 & 18 & 18 \\
\hline & \multirow[t]{3}{*}{$\mathrm{B}$} & \multirow[t]{3}{*}{ Harvest (t0) } & \multirow[t]{3}{*}{ CPUE ages $2 \&$ older (t0) } & $\mathrm{r}$ & -0.88 & -0.55 & 0.06 \\
\hline & & & & $p$ & $<0.00001$ & 0.006 & 0.6 \\
\hline & & & & df & 18 & 18 & 18 \\
\hline \multirow[t]{3}{*}{ MU4 } & \multirow[t]{3}{*}{ A1 } & \multirow[t]{3}{*}{ Harvest (t0) } & \multirow[t]{3}{*}{ ○ $\mathrm{L}_{50}(\mathrm{t} 2)$} & $\mathrm{r}$ & -0.26 & 0.14 & -0.19 \\
\hline & & & & $p$ & 0.15 & 0.72 & 0.22 \\
\hline & & & & $\mathrm{df}$ & 16 & 18 & 18 \\
\hline
\end{tabular}




$\begin{array}{ccccc}\text { Harvest (t0) } \quad \text { + } \mathrm{L}_{50}(\mathrm{t} 3) & \mathrm{r} & -0.07 & 0.05 & -0.19 \\ & p & 0.4 & 0.59 & 0.21 \\ & \mathrm{df} & 15 & 17 & 17\end{array}$

A2 Harvest (t0) $\quad$ $\mathrm{A}_{50}(\mathrm{t} 2)$

$\begin{array}{llll}\text { r } & -0.14 & 0.09 & -0.09\end{array}$

$\begin{array}{llll}p & 0.30 & 0.64 & 0.35\end{array}$

df $\quad 15 \quad 17 \quad 18$

Harvest (t0) $\quad$ $\mathrm{A}_{50}(\mathrm{t} 3)$

$\begin{array}{llll}\text { r } & \mathbf{- 0 . 5 1} & -0.32 & \mathbf{- 0 . 4 6}\end{array}$

$\begin{array}{llll}p & 0.02 & 0.1 & 0.03\end{array}$

$\begin{array}{lll}\text { df } & 14 & 16\end{array}$

B Harvest (t0) CPUE ages $2 \&$ older (t0)

$\begin{array}{lccc}\text { r } & \mathbf{- 0 . 8 1} & \mathbf{- 0 . 5 5} & -0.21 \\ p & <0.0001 & 0.005 & 0.18 \\ \text { df } & 19 & 19 & 19\end{array}$

$696 *$ tn indicates the variable was lagged $\mathrm{n}$ years in the analysis, e.g. in prediction $\mathrm{A}$, harvest ratio in the year it was measured ( $\mathrm{t} 0)$ was 697 related to length at maturity two $(\mathrm{t} 2)$ and three $(\mathrm{t} 3)$ years later. 
698 Table 4. Pearson correlation coefficients (r) for the model predictions C to E (Fig. 3 and Table

699 1). C1) CPUE of ages 2 and older and density of YOY; C2) CPUE of ages 2 and older and

700 CPUE of age 1; D1) density of YOY and female growth in first year (mean female size at age 1);

701 D2) CPUE of age 1 and female growth in second year (size increase from age 1 to age 2); E1)

702 growth in first year and female $\mathrm{L}_{50}$, and E2) growth in second year and female $\mathrm{L}_{50}$. Correlation

703 coefficients were estimated for the whole lake and for each of four management units (MU).

704 Values in bold are statistically significant at $p<0.05$. 


\begin{tabular}{|c|c|c|c|c|c|c|c|c|}
\hline \multirow{2}{*}{$\begin{array}{l}\text { Pre- } \\
\text { diction }\end{array}$} & \multirow[b]{2}{*}{ Independent variable } & \multirow[b]{2}{*}{ Dependent variable } & \multicolumn{5}{|c|}{ Management units } & \multirow{2}{*}{$\begin{array}{l}\text { Whole } \\
\text { Lake }\end{array}$} \\
\hline & & & & MU1 & MU2 & MU3 & MU4 & \\
\hline \multirow[t]{3}{*}{$\mathrm{C} 1$} & CPUE ages $2 \&$ older $(\mathrm{t} 0)$ & Density YOY (t1) & $\mathrm{r}$ & -0.16 & -0.12 & -0.04 & -0.09 & -0.22 \\
\hline & & & $p$ & 0.23 & 0.3 & 0.44 & 0.35 & 0.16 \\
\hline & & & $\mathrm{df}$ & 20 & 20 & 18 & 18 & 20 \\
\hline \multirow[t]{3}{*}{$\mathrm{C} 2$} & CPUE ages $2 \&$ older (t0) & CPUE age $1(\mathrm{t} 2)$ & $\mathrm{r}$ & -0.39 & -0.17 & 0.13 & -0.31 & -0.14 \\
\hline & & & $p$ & 0.03 & 0.24 & 0.68 & 0.11 & 0.27 \\
\hline & & & df & 19 & 19 & 14 & 15 & 19 \\
\hline \multirow[t]{3}{*}{ D1 } & Density YOY (t0) & q Growth 1st year & $\mathrm{r}$ & -0.29 & 0.15 & -0.3 & 0.25 & 0.003 \\
\hline & & (size at age 1$)(\mathrm{t} 0)$ & $p$ & 0.1 & 0.76 & 0.09 & 0.83 & 0.51 \\
\hline & & & df & 20 & 21 & 20 & 16 & 21 \\
\hline \multirow[t]{3}{*}{ D2 } & CPUE age $1(\mathrm{t} 0)$ & o Growth 2nd year & $\mathrm{r}$ & -0.18 & -0.07 & 0.3 & 0.2 & -0.12 \\
\hline & & (size change $1-2)(\mathrm{t} 0)$ & $p$ & 0.2 & 0.37 & 0.88 & 0.77 & 0.29 \\
\hline & & & $\mathrm{df}$ & 20 & 21 & 16 & 15 & 21 \\
\hline \multirow[t]{2}{*}{ E1 } & o Growth 1st year & $q \mathrm{~L}_{50}(\mathrm{t} 1)$ & $\mathrm{r}$ & 0.16 & -0.16 & -0.25 & 0.19 & -0.19 \\
\hline & $($ size at age 1$)(\mathrm{t} 0)$ & & $p$ & 0.76 & 0.23 & 0.14 & 0.75 & 0.2 \\
\hline
\end{tabular}




\begin{tabular}{|c|c|c|c|c|c|c|c|}
\hline & & $\mathrm{df}$ & 19 & 20 & 19 & 13 & 20 \\
\hline \multirow{3}{*}{$\begin{array}{l}\text { Growth 2nd year } \\
(\text { size change } 1-2)(\mathrm{t} 0)\end{array}$} & q $\mathrm{L}_{50}(\mathrm{t} 0)$ & $\mathrm{r}$ & 0.21 & -0.08 & -0.15 & -0.21 & -0.2 \\
\hline & & $p$ & 0.82 & 0.64 & 0.26 & 0.2 & 0.18 \\
\hline & & $\mathrm{df}$ & 20 & 21 & 19 & 15 & 21 \\
\hline
\end{tabular}

706 related to length at maturity two (t2) and three (t3) years later. 


\section{Figure captions}

708

709

710

711

712

713

714 715 starting year of this study.

Fig. 1. Map of Lake Erie showing the four management units (MUs) for yellow perch numbered from west to east (MU5 is within MU4 and is not shown). The black square in the lower right insert shows the location of Lake Erie within North America (modified from Belore et al. 2016).

Fig. 2. Estimates from 1975 - 2013 of Lake Erie yellow perch population size in millions (shading), harvest ratio (solid black line), instantaneous fishing mortality ( $\mathrm{F}_{\text {year }}{ }^{-1}$; solid gray line), exploitation ratio (black dash line). On the horizontal axis the black arrow indicates the

Fig. 3. Conceptual model of plasticity in individual life history describing the direct relationships between harvest, ages 2 and older abundance, YOY and age 1 abundance, growth and female age or size at $50 \%$ maturity as solid arrows. The overall cumulative indirect effect of harvest on maturity is shown as a dashed arrow. Time refers to the lag time in years between harvest and

721 each response (e.g. the effect of harvesting is expected to affect growth one and two years later).

722 The letter at each causal arrow indicates the predicted relationship shown in brackets under the 723 arrow and described in Tables 1 and 3: A) Increased harvest reduces female body age and length 724 at 50\% maturity; B) increased harvest lowers the abundance of ages 2 and older; C) fewer age 2 725 and older spawners reduces the abundance of younger age classes; D) lower abundance of 726 younger individuals increases individual juvenile growth rate; E) increased individual juvenile 727 growth rate decreases female age and length at 50\% maturity. 
728 Fig. 4. Time series of female length and age at 50\% maturity ( $\mathrm{L}_{50}$ and $\mathrm{A}_{50}$, respectively) for 729 yellow perch from Lake Erie. Times series are provided for the entire lake and separately for 730 each management unit. Whole lake (panels A, B), MU1 (panels C, D), MU2 (panels E, F), MU3 731 (panels G, H), and MU4 (I, J). Vertical bars express 95\% confidence intervals. Estimates of $\mathrm{L}_{50}$ 732 and $\mathrm{A}_{50}$ indicated by an open circle (o) are unreliable $\left(\mathrm{A}_{50} 95 \% \mathrm{CI}> \pm 10.2\right.$ years and $\mathrm{L}_{50} 95 \% \mathrm{CI}$ $733> \pm 200.0 \mathrm{~mm})$. Note the changed vertical scale among MUs.

Fig. 5. Relationships between length at 50\% maturity $\left(\mathrm{L}_{50}\right)$ and age at $50 \%$ maturity $\left(\mathrm{A}_{50}\right)$ for 736 female yellow perch in Lake Erie between 1991 and 2013 ( $n=23$ annual cohorts). Regression 737 equations and statistical details for the whole lake and MU's: Whole lake; $\mathrm{L}_{50}=121.2+$ $18.2 * \mathrm{~A}_{50}, \mathrm{R}^{2}=0.45, p<0.001 ; \mathrm{MU} 1, \mathrm{~L}_{50}=104.9+24.1 * \mathrm{~A}_{50}, \mathrm{R}^{2}=0.54, p<0.0001 ; \mathrm{MU} 2, \mathrm{~L}_{50}=$ $136.9+11.4 * \mathrm{~A}_{50}, \mathrm{R}^{2}=0.28, p<0.01 ; \mathrm{MU} 3, \mathrm{~L}_{50}=125.0+16.1 * \mathrm{~A}_{50}, \mathrm{R}^{2}=0.40, p<0.0001 ;$ MU4, $\mathrm{L}_{50}=78.8+35.3 * \mathrm{~A}_{50}, \mathrm{R}^{2}=0.46, p<0.001$.

Fig. 6. Panels summarizing relationships predicted by the plastic life history model (Fig. 3, Table 1) for the whole lake: A) Harvest ratio and female $L_{50}$ two years later; B) harvest ratio and

744 female $\mathrm{L}_{50}$ three years later; $\mathrm{C}$ ) harvest ratio and CPUE of ages 2 and older (regression line: $\ln ($ CPUE ages 2 and older $)=-0.01-0.99 * \ln ($ harvest ratio $\left.), \mathrm{R}^{2}=0.92, p<0.0001\right)$; D) CPUE of ages 2 and older and density of YOY year later; E) CPUE of ages 2 and older and CPUE of age 1 two years later; F) density of YOY and female growth in first year; G) CPUE of age 1 and

748 female growth in second year; H) female growth in first year and female $\mathrm{L}_{50}$ year later; I) female 749 growth in second year and female $\mathrm{L}_{50}$. The sign appearing in parentheses in the upper right 
750 corner of each panel indicates the predicted relationship between variables. With the exception of

751 C, all correlation coefficients were non-significant $(p>0.05)$. 


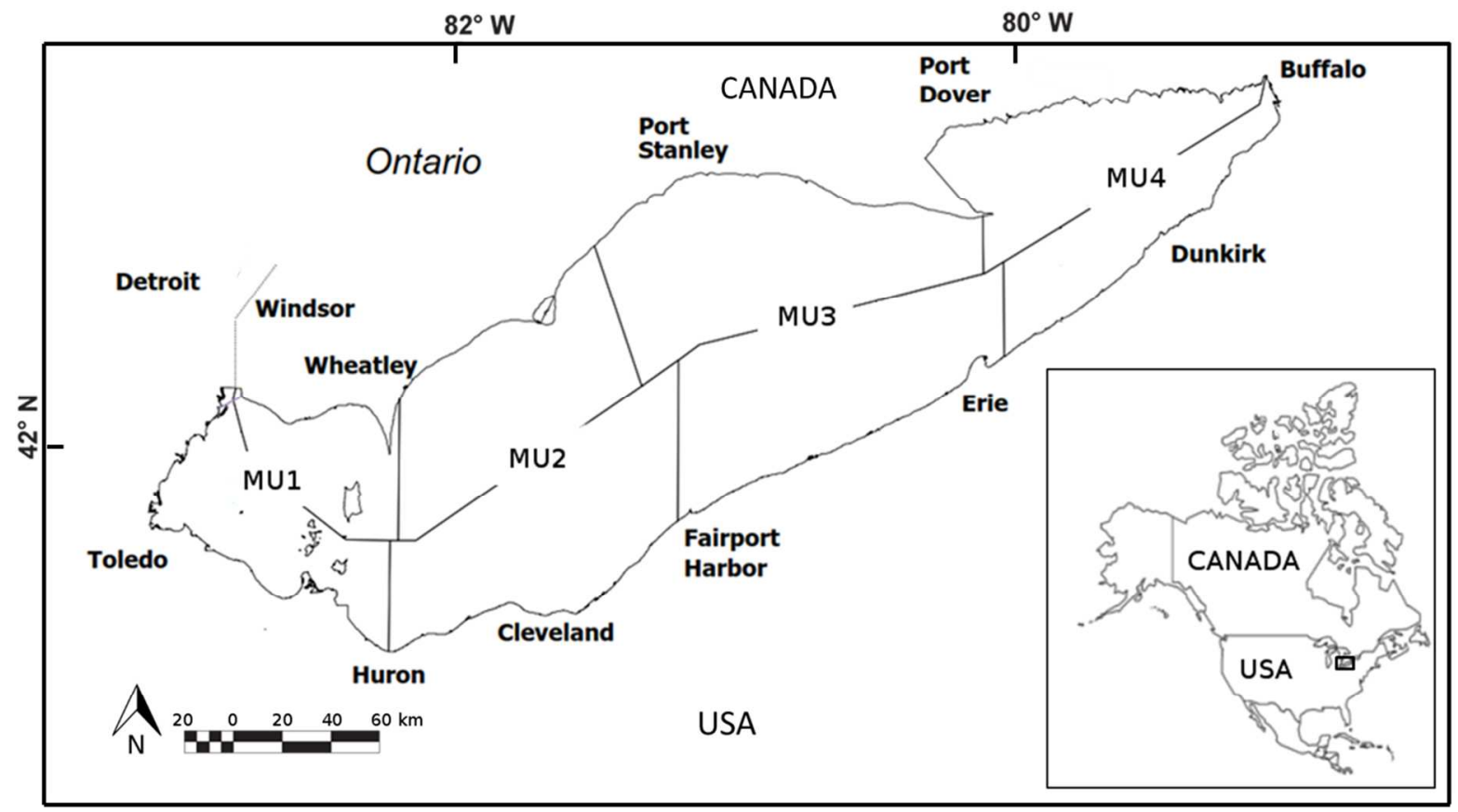

752

753 Fig. 1. Map of Lake Erie showing the four management units (MUs) for yellow perch numbered

754 from west to east (MU5 is within MU4 and is not shown). The black square in the lower right

755 insert shows the location of Lake Erie within North America (modified from Belore et al. 2016). 


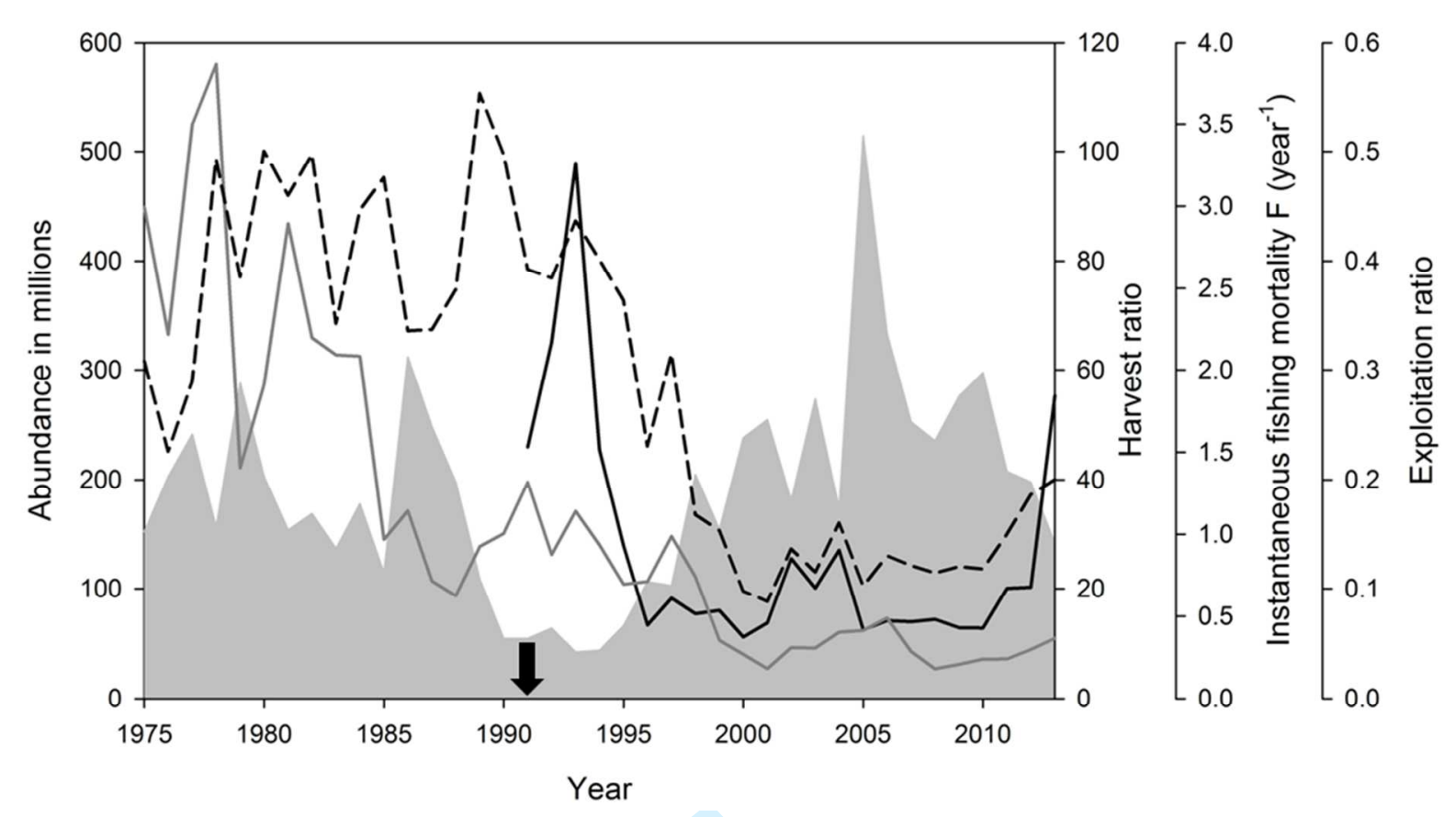

757 Fig. 2. Estimates from 1975 - 2013 of Lake Erie yellow perch population size in millions

758 (shading), harvest ratio (solid black line), instantaneous fishing mortality ( $\mathrm{F}_{\text {year }}{ }^{-1}$; solid gray

759 line), exploitation ratio (black dash line). On the horizontal axis the black arrow indicates the 760 starting year of this study. 
761

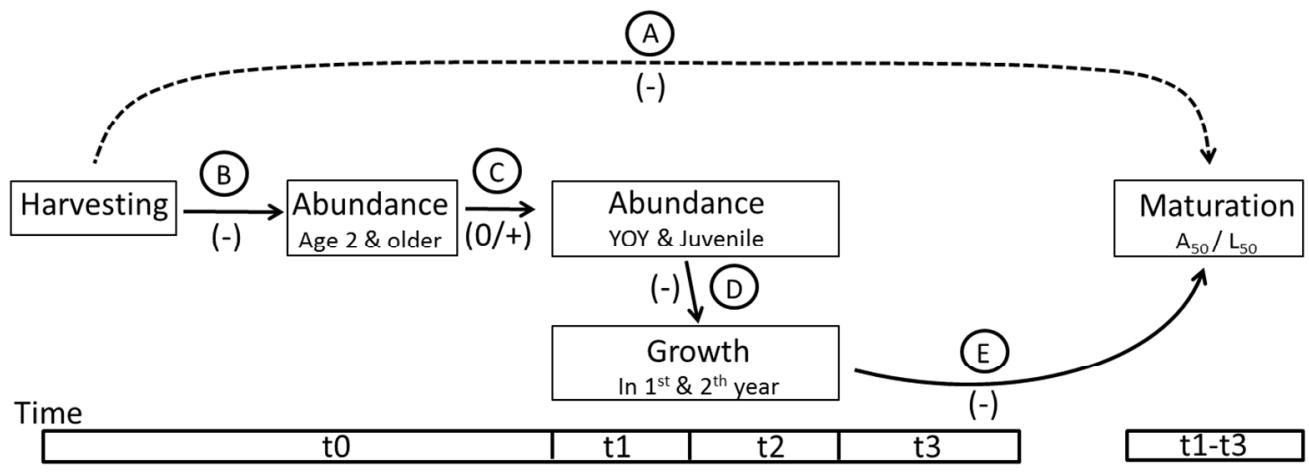

762 Fig. 3. Conceptual model of plasticity in individual life history describing the direct relationships

763 between harvest, ages 2 and older abundance, YOY and age 1 abundance, growth and female age

764 or size at $50 \%$ maturity as solid arrows. The overall cumulative indirect effect of harvest on

765 maturity is shown as a dashed arrow. Time refers to the lag time in years between harvest and

766 each response (e.g. the effect of harvesting is expected to affect growth one and two years later).

767 The letter at each causal arrow indicates the predicted relationship shown in brackets under the

768 arrow and described in Tables 1 and 3: A) Increased harvest reduces female body age and length

769 at 50\% maturity; B) increased harvest lowers the abundance of ages 2 and older; C) fewer age 2

770 and older spawners reduces the abundance of younger age classes; D) lower abundance of

771 younger individuals increases individual juvenile growth rate; E) increased individual juvenile

772 growth rate decreases female age and length at 50\% maturity. 

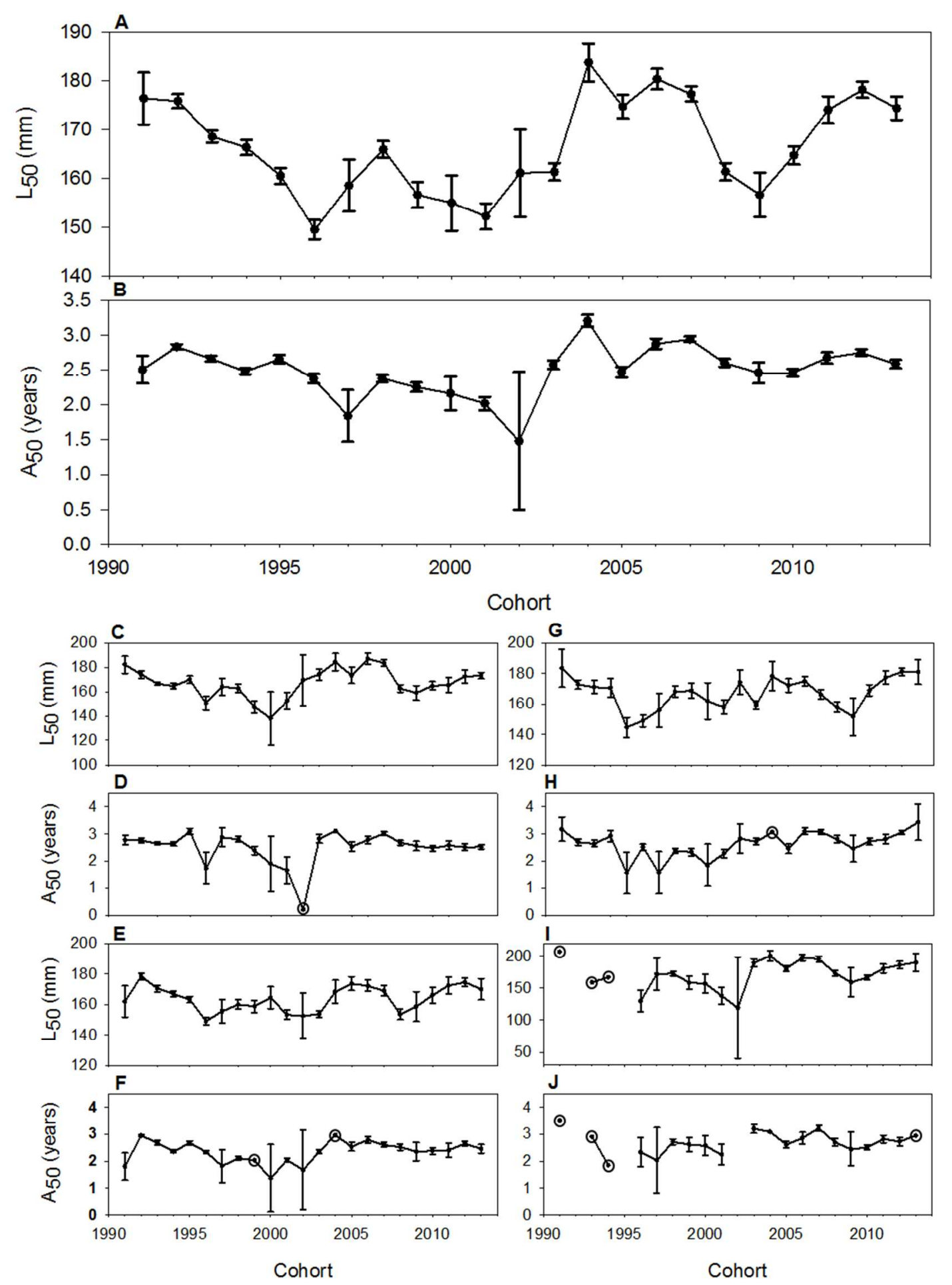
775 Fig. 4. Time series of female length and age at 50\% maturity ( $L_{50}$ and $A_{50}$, respectively) for 776 yellow perch from Lake Erie. Times series are provided for the entire lake and separately for 777 each management unit. Whole lake (panels A, B), MU1 (panels C, D), MU2 (panels E, F), MU3 778 (panels G, H), and MU4 (I, J). Vertical bars express 95\% confidence intervals. Estimates of $\mathrm{L}_{50}$ 779 and $\mathrm{A}_{50}$ indicated by an open circle (o) are unreliable $\left(\mathrm{A}_{50} 95 \% \mathrm{CI}> \pm 10.2\right.$ years and $\mathrm{L}_{50} 95 \% \mathrm{CI}$ $780> \pm 200.0 \mathrm{~mm}$ ). Note the changed vertical scale among MUs. 


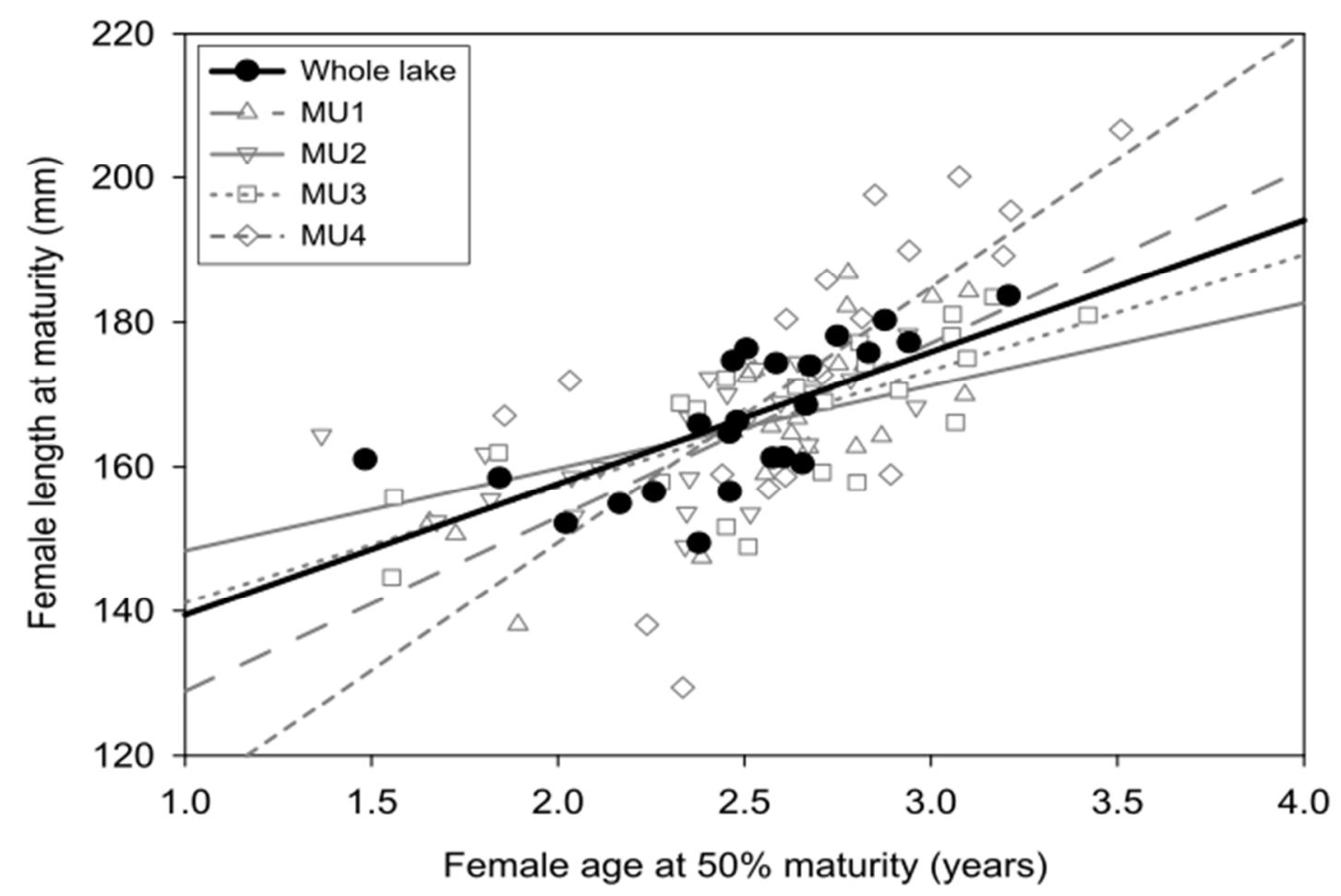

781

782 Fig. 5. Relationships between length at 50\% maturity $\left(\mathrm{L}_{50}\right)$ and age at $50 \%$ maturity $\left(\mathrm{A}_{50}\right)$ for 783 female yellow perch in Lake Erie between 1991 and 2013 ( $n=23$ annual cohorts). Regression 784 equations and statistical details for the whole lake and MU's: Whole lake; $\mathrm{L}_{50}=121.2+$ $78518.2 * \mathrm{~A}_{50}, \mathrm{R}^{2}=0.45, p<0.001 ; \mathrm{MU} 1, \mathrm{~L}_{50}=104.9+24.1 * \mathrm{~A}_{50}, \mathrm{R}^{2}=0.54, p<0.0001 ; \mathrm{MU}_{2}, \mathrm{~L}_{50}=$ $786136.9+11.4 * \mathrm{~A}_{50}, \mathrm{R}^{2}=0.28, p<0.01 ; \mathrm{MU} 3, \mathrm{~L}_{50}=125.0+16.1 * \mathrm{~A}_{50}, \mathrm{R}^{2}=0.40, p<0.0001 ;$

$787 \quad \mathrm{MU} 4, \mathrm{~L}_{50}=78.8+35.3 * \mathrm{~A}_{50}, \mathrm{R}^{2}=0.46, p<0.001$. 

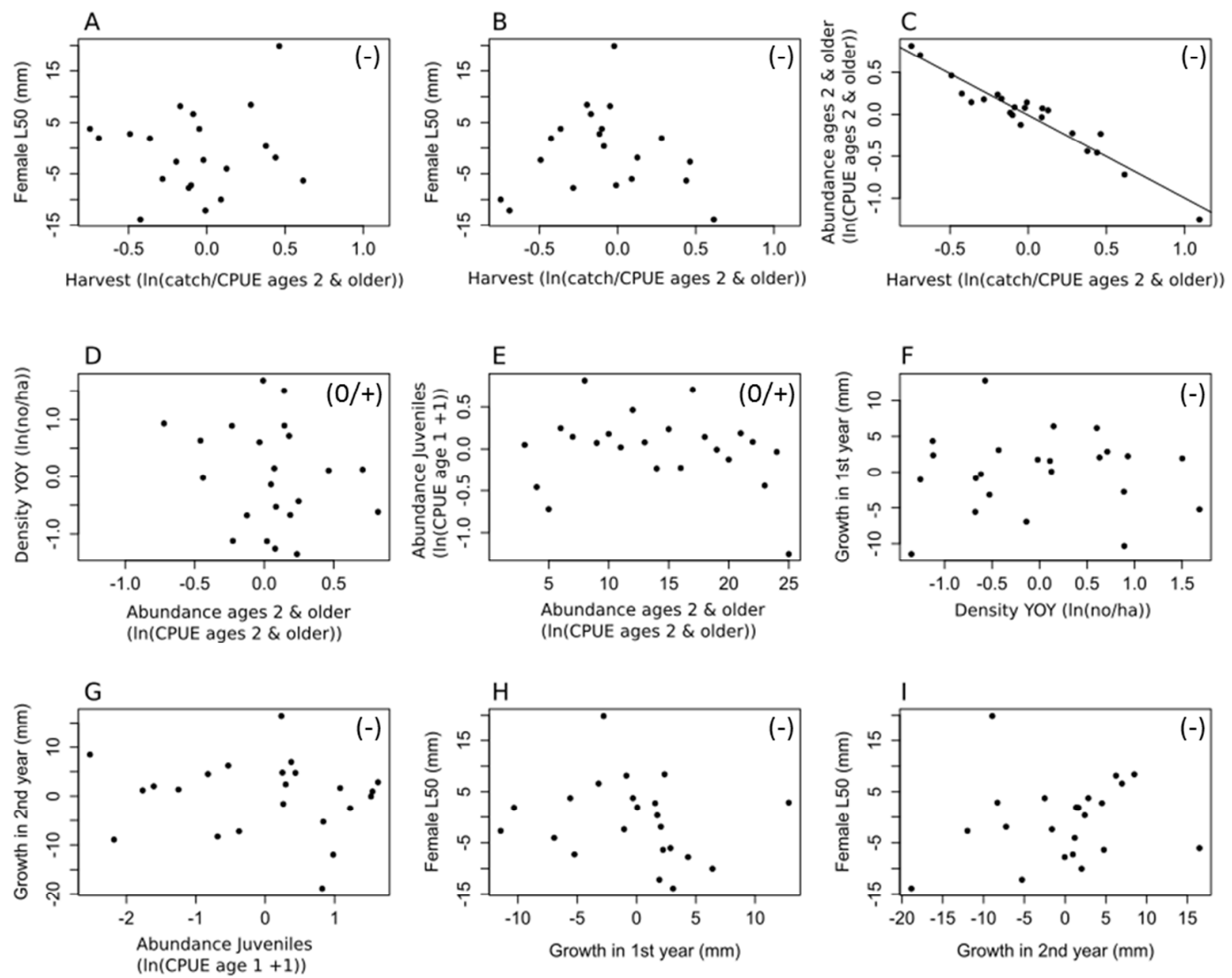

Fig. 6. Panels summarizing relationships predicted by the plastic life history model (Fig. 3, Table 1) for the whole lake: A) Harvest ratio and female $L_{50}$ two years later; B) harvest ratio and

791 female $\mathrm{L}_{50}$ three years later; C) harvest ratio and CPUE of ages 2 and older (regression line: $\ln ($ CPUE ages 2 and older $)=-0.01-0.99 * \ln ($ harvest ratio $\left.), \mathrm{R}^{2}=0.92, p<0.0001\right)$; D) CPUE of ages 2 and older and density of YOY year later; E) CPUE of ages 2 and older and CPUE of age 1 two years later; F) density of YOY and female growth in first year; G) CPUE of age 1 and

795 female growth in second year; H) female growth in first year and female $\mathrm{L}_{50}$ year later; I) female 796 growth in second year and female $\mathrm{L}_{50}$. The sign appearing in parentheses in the upper right 
797 corner of each panel indicates the predicted relationship between variables. With the exception of

798 C, all correlation coefficients were non-significant $(p>0.05)$. 